\title{
Cross-faculty proximity and academic entrepreneurship: the role of business schools
}

\author{
Maximilian Goethner ${ }^{1} \cdot$ Michael Wyrwich $^{2}$
}

Published online: 27 March 2019

(c) The Author(s) 2019

\begin{abstract}
Over the past decades, entrepreneurial activity has started to be considered a third mission of higher education institutions. Our study examines the extent to which entrepreneurship at universities is driven by spatial proximity between university faculties. To this end, we use a new dataset that links information on business idea generation by faculties of German universities between 2007 and 2014 with comprehensive data on structural characteristics of these universities and faculties (e.g., number of academic staff, students, industry funding). Our analysis shows that the emergence of entrepreneurial ideas in natural sciences is positively affected by proximity to business schools. This pattern suggests the presence of knowledge flows between these two types of university faculties as an important source of science-based and technology-oriented business ideas. We do not find such a relationship between proximity to business schools and other faculties.
\end{abstract}

Keywords Academic entrepreneurship - Knowledge spillover - Spatial proximity · Entrepreneurial human capital

JEL classifications D24 $\cdot \mathrm{L} 26 \cdot \mathrm{M} 13 \cdot \mathrm{O} 31 \cdot \mathrm{O} 32$

\section{Introduction}

The increasing need to produce, transfer, and exploit commercially viable research findings has led today's universities to rethink and adjust their role. With the Massachusetts Institute of Technology (MIT) and Stanford University as early archetypes, higher education institutions have begun to expand their traditional mission of performing research and training of highly qualified people to include more applied research of greater commercial relevance, and to diffuse technical knowledge and provide technical support to industry (Etzkowitz 2000, 2003; Thursby and Thursby 2002). As a result, mainly in the U.S.

Michael Wyrwich

m.wyrwich@rug.nl

1 School of Economics and Business Administration, Friedrich Schiller University Jena, 07743 Jena, Germany

2 Faculty of Economics and Business, University of Groningen, Nettelbosje 2, 9747 AE Groningen, Netherlands 
and Western Europe, universities have become increasingly entrepreneurial (Shane 2004; Siegel et al. 2007).

Ever since this transformation process started, fostering research commercialization has gained importance and became one of today's priority issues for policy-makers and public authorities. In recent decades, Western governments introduced many measures to actively promote the transformation of scientific knowledge into innovative and practical goods (Link and Scott 2010; Lockett et al. 2005; OECD 2003). The Bayh-Dole Act of 1980 is probably the best-known piece of legislation for that purpose.

Accompanying this development, spin-off entrepreneurship, patenting, licensing and other activities of knowledge and technology transfer from universities to the private sector, have attracted considerable scholarly attention (see Astebro and Bazzazian 2011; Rothaermel et al. 2007; Perkmann et al. 2013 for comprehensive overviews). An important part of this literature has sought to explain institutional differences in technology transfer. For example, it has been found that the level of industry funding and the nature of research within the university (O'Shea et al. 2005; Powers and McDougall 2005), the size and quality of research faculty (Di Gregorio and Shane 2003; O'Shea et al. 2005), and a university's entrepreneurial tradition (Lockett and Wright 2005; Shane 2004) all are strong predictors of the probability and number of spin-off companies. These prior efforts notwithstanding, important questions are still unanswered. From a process perspective of spin-off venture creation (Rasmussen 2011), it is less clear whether and how characteristics of the university and its faculty exert influence on the initial stage, i.e., the emergence of the science-based business idea. Generally, the business idea represents the core of the entrepreneurial process, defined by Grandi and Grimaldi (2005, p. 826) as "the complex of products/services, knowledge, competencies, market, and technologies that are necessary to run a business". As Audretsch (2007) emphasized, not only is the success of a new venture rooted in the quality, newness, and potential of its business idea, but the success of whole entrepreneurial societies depends on the generation (and exploitation) of innovative business ideas.

This paper seeks to elucidate the generation of innovative business ideas in the university context. We add to the academic entrepreneurship literature by proposing that knowledge flows between business schools (BSs) and other university faculties are one important source of science-based and technology-oriented business ideas. For our analysis, we use a comprehensive dataset that links information on business idea generation by faculties of German universities with data on structural characteristics of these universities and faculties. Moreover, our dataset allows shifting the analysis of institutional differences in entrepreneurial activity from the well-studied university level to the relatively neglected faculty level. This shift in perspectives is particularly important as previous organizational studies highlight the faculty level for understanding enterprising behavior among academic research scientists (Bercovitz and Feldman 2008; Kenney and Goe 2004; Rasmussen et al. 2014). Our empirical focus is on the role of BSs for the emergence of entrepreneurial ideas across natural science and engineering faculties of universities. BSs can be conducive for the emergence of entrepreneurial ideas at universities (Wright et al. 2009). We will argue and show that proximity to BSs is positively related to the emergence of entrepreneurial ideas in other faculties.

Our key contribution to the literature is that, as far as we are aware, our paper is the first study to present systematic data that offers support for the idea that spatial proximity between faculties affects university entrepreneurship. While there is an emerging literature that stresses the importance of proximity between university actors and private sector partners (e.g., Adams 2002; Abramovsky et al. 2007; Abramovsky and Simpson 2011; Muscio 
2013), prior research does not consider the influence of intra-university proximity on the commercialization of scientific knowledge. We demonstrate that distance between university actors matters as well. In particular, we find that spatial proximity to BSs has a positive impact on the generation of entrepreneurial ideas in natural science faculties while there is no relationship to entrepreneurship in engineering sciences. These results are robust to several robustness checks including 2SLS instrumental variable regressions.

Overall, this study suggests that interdisciplinary social interactions and knowledge flows between faculties comprise important aspects of the social context in university entrepreneurship. These results will resonate with scholars emphasizing contextual influences upon entrepreneurial behavior and innovation (Autio et al. 2014; Wright 2014).

\section{Proximity, cross-faculty knowledge flows, and academic entrepreneurship: setting the scene}

Our line of argumentation is embedded in the general literature on the role of proximity for peer effects, communication patterns, and knowledge flows (e.g., Bulte and Moenaert 1998; Glaeser and Sacerdote 2000; Grinblatt et al. 2008; Bandiera et al. 2010; Nanda and Sorenson 2010). There is also a burgeoning strand of literature investigating social network formation in the university context (e.g., Sacerdote 2001; Zimmerman 2003; Mayer and Puller 2008; Marmaros and Sacerdote 2006). Peer effects and local network ties are essential to understanding scientists' engagement in technology transfer activities (e.g., Link et al. 2007; D'Este and Patel 2007; Abreu and Grinevich 2013; Heblich and Slavtchev 2014; Tartari et al. 2014). In this respect, Murray (2004, p. 643) vividly describes the role of social capital. It comprises, for example, "the local laboratory network-a network to current and former students and advisors established by the inventor through his laboratory life. The second form of social capital is a wider, cosmopolitan network of colleagues and co-authors established through the social patterns of collaboration, collegiality and competition that exemplify scientific careers." Bozeman and Mangematin (2004, p. 565), put it more literally: "scientists and engineers are as dependent upon social networks as they are upon such tangible scientific tools as electron microscopes, supercomputers and synchrotrons."

We contribute to the literature by arguing that interdisciplinary network ties and peer effects exert an influence on the level of academic entrepreneurship. Entrepreneurship scholars already pointed out that people with an interdisciplinary background are better placed to recognize and act upon entrepreneurial opportunities (Shane 2000; Bercovitz and Feldman 2008). In this regard, we propose that Business Schools (BSs) play a pivotal role as they may induce "cross-faculty knowledge spillovers" that spur the emergence of entrepreneurial ideas, for example, among faculties of natural science and technology.

Business schools are educational institutions that typically teach courses in areas such as finance, marketing, and strategy. In response to the increasing importance of entrepreneurial activity for economic growth and development, the number of BSs that expanded their curricula to include entrepreneurship-related courses and programs is growing rapidly and globally (Kuratko 2005). Despite an ongoing debate about how to effectively teach 'for' entrepreneurship (rather than teaching 'about' it) (Kirby 2004; Kuratko 2005), scholars agree that entrepreneurship education programs may be a key instrument for fostering technology commercialization and entrepreneurial activity (Wright et al. 2009). Most empirical studies find positive overall effects of BS education on entrepreneurial skills and 
competencies, perceptions of entrepreneurship and entrepreneurial outcomes (e.g., Martin et al. 2013; Bae et al. 2014). Accordingly, BSs are regarded as a vital component of a university's entrepreneurial ecosystem (Boh et al. 2016; Bischoff et al. 2018).

Wright et al. (2009) discuss two channels pertaining to the role of BSs for entrepreneurship at universities. The first channel refers to the provision of courses and seminars on financial planning, accounting, marketing as well as specific entrepreneurship classes where undergraduates and post-graduates learn about writing a business plan, marketing new products, or strategies to negotiate with potential investors. University researchers with significant technological expertise often do not possess the necessary skills to bring their inventions to the market or, for that matter, to spot new opportunities (Vohora et al. 2004). Attending general business and specific entrepreneurship classes offered at BSs could thus induce a formal transfer of generic managerial and entrepreneurial competencies. ${ }^{1}$

The second channel refers to the direct involvement of BS faculty in the start-up process either through becoming an entrepreneur themselves and starting a firm, serving as (co)founders or board members of a start-up or by taking the role of an external consultant providing business-related knowledge to technically savvy would-be entrepreneurs.

In addition to formal entrepreneurship education and training, cross-faculty knowledge spillovers from BSs to other faculties like natural science and engineering may unfold through informal and occasional knowledge exchange. Social interaction with BS faculty on an informal basis (e.g., during lunch breaks, social events) might raise science and technology faculty's awareness of the commercial potential of their research and eventually increase their desire to exploit this potential by founding their own business. Research showed that knowing where business-related advice is available already contributes to scientists' perceived efficacy with respect to starting an entrepreneurial career (Goethner et al. 2012). Altogether, cross-faculty knowledge spillovers emanating from BSs are about social contacts at the local university which make peers from other faculties aware of entrepreneurial ideas, promote their development and allow potential academic entrepreneurs to draw on local expertise (e.g., counseling, advice).

The effectiveness of cross-faculty knowledge flows from BSs should further be a function of spatial proximity. This assumption draws on insights from different strands of literature. First of all, papers on agglomeration externalities argue that density and proximity of actors increases the frequency of (face-to-face) interaction among heterogeneous actors, which provides the basis for serendipitous labor market matching, sharing of knowledge, and effective learning (e.g., Jacobs 1969; Helsley and Strange 1991; Glaeser and Sacerdote 2000; Storper and Venables 2004). Second, there is a literature stressing that spatial distance is also related to the costs of communication and the benefits of social interaction which was shown to matter in the university context (e.g., Festinger et al. 1963; Holahan et al. 1978; Sacerdote 2001; Marmaros and Sacerdote 2006; Agrawal and Goldfarb 2008). The argument is illustrated by Marmaros and Sacerdote (2006) who argue that the benefits of social interaction comprise the flow of information and ideas as well as the utility from sharing similar experiences. The benefit is likely to increase with the number of previous contacts with the respective person. Costs are reflected by the time of interaction and search for useful social contacts. Distance is a considerable cost factor if person and value of interaction are unknown. The authors find that proximity has a large effect on the likelihood of social interaction among individuals at the university campus.

\footnotetext{
1 For a critical discussion of the relevance of BSs for the formation and transfer of managerial competencies, see Wright et al. (2009, p. 565f).
} 
Furthermore, increasing distance between faculties decreases the likelihood of chance encounters of students and faculty staff with a different background in the urban neighborhood. The urban space provides interaction-promoting facilities similar to what Allen (1977) described in the organizational context. In a similar vein, much of the traffic in a neighborhood results from the movement of people to and from certain types of facilities they have to use during the day and when these facilities are sprawled. Among them, one can cite lecture theatres, student dorms, gyms, students clubs, bars, cafeterias. Allen (1977) shows that laboratory design that increases the number of interaction-promoting facilities can affect the extent of communications positively. Such mechanisms may also be at work for university architectures.

A positive effect of proximity on peer effects, communication patterns, and knowledge flows is also emphasized in sociological and psychological theories (for an overview, see Rivera et al. 2010, pp. 105-107; see also Allen 1977, pp. 334-335 for earlier studies) and in economic geography. Regarding the latter Boschma (2005) discusses how geographic proximity relates to innovation. The argument is that spatial proximity is associated with knowledge externalities. Short distance enhances opportunities for exchanging tacit (noncodified) knowledge which is crucial for innovation and entrepreneurship. The geographic bounding of knowledge transmission processes is confirmed in numerous empirical studies (e.g., Jaffe et al. 1993; Audretsch and Feldman 1996; Howells 2002; Singh and Marx 2013; Belezon and Schankerman 2013). Against this background, it comes as no surprise that recent research demonstrates the importance of local proximity for the formation and effectiveness of university-industry linkages (e.g., Adams 2002; Abramovsky et al. 2007; Abramovsky and Simpson 2011; Muscio 2013). Abramovsky and Simpson (2011) argue that firms may benefit from proximity to universities by drawing on the expertise of university staff or research students through consultancy or direct recruitment, or to access codified and non-codified knowledge more informally and formally (e.g., in the form of research joint ventures). These mechanisms are similar to those we have in mind for the cross-faculty level. Therefore, we expect that research departments benefit from proximity to BSs, regarding knowledge transfer (i.e., generation of university spin-offs) in a similar way. The literature mentioned above unanimously states that geographical distance is the most important form of distance for predicting social interaction. This does not mean that other forms of distance (e.g., social, cultural, institutional) are not relevant as well (see also, Boschma 2005).

\section{Empirical strategy}

\subsection{Database}

Our analysis is focused on the distribution of science-based business ideas across university faculties. We make use of publicly available information on business start-up grants assigned to university members between 2007 and 2014 under the framework of the German "EXIST-Gründerstipendium" initiative which is a main program line within the policy program "EXIST: Promotion of university-based start-ups" (http://www.exist.de).

Started in 1998, EXIST is a federally funded part of the German government's "Hightech Strategy for Germany" and is co-financed by the European Social Funds (ESF). The program aims at improving the conditions for academic entrepreneurship. Key objectives of EXIST thus include the establishment of an entrepreneurial culture at German HEIs, 
the continuous transfer of research results into marketable products and services, the promotion of highly innovative research-based business ideas, and a significant increase in entrepreneurial activity by academics. The EXIST program follows a dual strategy. One building block is supporting universities and providing indirect assistance for individuals and start-up projects. In this respect, there have been several phases of EXIST program lines that aimed at creating entrepreneurship-facilitating structures at universities since the late 1990s. In support of these activities, universities receive an allowance from the German Federal Ministry of Economics and Technology over three years (e.g., EXIST 2013; Kulicke 2014).

The so-called "EXIST-Gründerstipendium" (EXIST start-up grant), is one of the main policy instruments regarding direct financial support to nascent academic entrepreneurs within the EXIST policy framework. The direct support is the second building block of the EXIST initiative. The EXIST start-up grant was introduced in 2007. The grant enables founders to develop a business model, test its economic viability, secure the required sources of funding and take the first steps in the process of developing the business (Kulicke 2014). At the same time, the grant reduces personal financial risks usually involved in starting up. For the maximum of one year, the living expenses of the founders are covered by the program. It offers a monthly scholarship for founders holding a Ph.D. $(2.500 €)$, university graduates $(2.000 €)$, and students $(800 €)$. Besides, successful applicants can get start-up related coaching (for up to $5.000 €$ ), funding for materials and equipment (up to $10.000 €$ for solo start-ups and 17.000 for team start-ups) and, where applicable, child benefit of $100 €$ per month and child. During the one-year funding period, program participants have free access to the infrastructure of the university or research institution (such as workshops, labs, computer centers) and usually get office space there. The university also provides technical assistance and counseling, while a designated mentor (e.g., university professor, expert researcher) guides the entrepreneurial project (EXIST 2013).

Grant applications are evaluated by the Project Management Agency Jülich (PTJ), which has been commissioned by the German Federal Ministry of Economics and Technology to implement the EXIST program. To be eligible for funding, applications have to fulfill several requirements. First of all, only scientists, former academic associates (up to 5 years after graduation/leaving the institution), and students (who have completed at least half of their courses at the time of application) of all German universities or scientists from public research institutes are supported. Members of funded start-up projects are further required to combine technical knowledge and skills related to the innovative technologyoriented business idea with management competencies. Finally, sponsorship is limited to high-potential start-up projects that involve the introduction of product or process innovations or innovative services and have clear prospects for economic success.

We rely on EXIST business start-up grants because we are interested in the emergence of entrepreneurial ideas. The data are suited for capturing formalized entrepreneurial ideas. The ventures are in the very early seed stage long before registering the business or making first sales. ${ }^{2}$ The data on assigned EXIST business start-up grants was derived from the "funding catalog" ("Förderkatalog") of the Federal Ministry of Economy and Technology and the Federal Ministry of Education and Research. ${ }^{3}$ The data comprise the name of the

\footnotetext{
${ }^{2}$ Requests for venture capital are very unlikely in this very early stage of the entrepreneurial process (e.g., Auerswald 2007).

3 http://foerderportal.bund.de/foekat/jsp/StartAction.do.
} 
university and the executing faculty that applied successfully for the grant. Furthermore, there is information on the year of application.

The information on university and faculty allowed us to combine the data with the University Statistics of the German Federal Statistical Office, which provides information about every university in Germany (Statistisches Bundesamt, various volumes) and contains, for example, the number of students, academic personnel, graduates, as well as the amount of Third-Party Funding. This information is distinguished by nine disciplines: humanities (such as cultural and language sciences), sports science, social sciences, natural sciences, medicine, veterinary medicine, agriculture and nutrition science, engineering as well as arts and culture-related studies (for details, see Fritsch and Aamoucke 2013) which we call "faculties" in the following. We assigned start-up grants to single faculties of universities. Please note that the data from "Förderkatalog" only provide information on successful grant applications.

\subsection{Sample}

In order to be suited for the empirical analysis, a university has to have more than one faculty in one city. Otherwise, cross-faculty spillovers are impossible. Based on this criterion, our dataset comprises 2072 faculty-year observations for the period between 2007 and 2014 that consist of observations from humanities, sports sciences, social sciences, natural sciences, engineering, and arts and culture. The raw dataset, before data cleaning, includes faculties of 57 German universities with 642 EXIST start-up grants in total. ${ }^{4}$ There are many differences concerning the number of start-up grants across universities and faculties. The highest annual number of start-up grants per faculty was obtained by the Social Sciences at Ludwig-Maximilians-University Munich where the EXIST initiative supported 10 start-up projects in 2010. Table 1 demonstrates that the likelihood of having at least one start-up grant per faculty and year is highest among natural sciences followed by engineering and social sciences. These faculties are ahead of the faculties of humanities, sports sciences as well as arts and culture.

\subsection{Proximity to business schools}

Our main variable of interest is proximity to business schools (BSs) which we measure by distance in walking minutes. BSs at German universities are embedded in departments offering both economics and business administration classes. Therefore, "BS" henceforth refers to departments of Economics and Business Administration (EBA). Cross-faculty effects of BSs should increase with decreasing distance to other faculties due to a higher likelihood and extent of social interaction between faculty members. The distance is measured on the basis of the locations of faculties at the university campus. The measurement procedure required the building of "clusters" of important facilities for each faculty that can be regarded as the centers of research and teaching. Studying the campus maps of the universities in our final sample, it became apparent that significant research and teaching

\footnotetext{
4 An overview of the data cleaning procedures is provided in "Appendix A". There are 4 out of 57 universities which have no business school (Bauhaus University Weimar, University of Erfurt, University of Frankfurt/Oder, and Technical University of Hamburg-Harburg). Therefore, these universities are dropped from the analysis. For a list of the 53 universities in the sample, see Table 6.
} 
facilities of a faculty are clustered in no more than four sites. The mail addresses of the four largest sites of a faculty were used to calculate the distance in walking minutes following Google Maps. ${ }^{5}$ The same source was used in previous research on proximity and university knowledge spillover (Belenzon and Schankerman 2013).

We carried out the above exercise only for natural and engineering sciences. BSs are part of the social science faculty. Nearly all successful grant applications in Social Sciences can be assigned to BSs. Therefore, analyzing how the prevalence of non-BS projects within the social sciences is affected by distance to the BS is not sensible. For other sciences we abstained from an analysis since the number of facilities, for example, in humanities is so huge that determining distances of single facilities to the BS is not feasible. Given the lower number of entrepreneurial projects from these faculties, it is also unlikely to find systematic patterns in the data. Finally, data limitations prevented us from considering medical science as well (see "Appendix A").

\subsection{Model and method}

We analyze the number of successful EXIST start-up grant applications across German universities at the faculty level for natural and engineering sciences between 2007 and 2014. Our empirical strategy relies on OLS and instrumental variables regressions. The regressions are carried out separately for each faculty. Standard errors are clustered at the university-faculty level. The clustering procedure corrects the standard errors for similar values of the cluster variable and controls for serial correlation. This is important to account for the panel structure of the data (Cameron and Trivedi 2009, pp. 621, 627). ${ }^{6}$ We lag the time-varying continuous variables by three years in order to avoid simultaneity bias. ${ }^{7}$ The basic relationship of the underlying model reads as follows:

$$
E_{X I S T} T_{f u, t}=\alpha+\beta * P R O X_{-} B S_{f u}+U_{N I F A C_{f u, t-3}^{\prime}}^{\prime}+R E G_{r, t-3}^{\prime} * D_{t}+\varepsilon_{f u, r, t-3}
$$

The dependent variable $\left(E X I S T_{f u, t}\right)$ is the annual number of business start-up grants over the number of eligible faculty members (academic personnel, students, recent graduates) per faculty of a respective university $f u$ at time $t$. This variable can assume the value of zero as well. In a robustness check, we use the number of business start-up grants as an alternative outcome variable. Our main variable of interest measures proximity between natural science and engineering faculties to the local BS in walking minutes $\left(P R O X \_B S_{f u}\right)$. It is time-invariant over the observation period. Furthermore, the analysis includes a vector of control variables for faculty-specific characteristics and characteristics on the level of the university the faculty belongs to that might affect university entrepreneurship $\left(\right.$ UNIFAC $\left._{f u, t-3}^{\prime}\right)$ (see Table 7 for a definition of variables and Table 8 for summary statis-

\footnotetext{
${ }^{5}$ Some faculties have small separate institutes at spots distant to sites hosting most of the teaching and research facilities of a faculty. We investigated whether regular teaching takes place at these spots. If there is just one separate institute without teaching activities, the respective sites are not considered as a cluster of significant research and teaching. We thank Steve Langheinrich for outstanding research assistance for determining these clusters and distances between faculties.

${ }^{6}$ For a similar application, see Fritsch and Falck (2007).

7 The lag is about three years since structural characteristics are likely to affect the emergence of business ideas in the longer run. There are also data restrictions for the most recent years of the observation period. Therefore, we would lose several observations when assuming a one or two-year lag.
} 
Table 1 Start-up grants per faculty and year across universities in our final sample

\begin{tabular}{|c|c|}
\hline Natural sciences & $\begin{array}{l}\text { Total Grants: } N=301 \\
\text { Share of faculty-year observations with } \\
\text { at least one grant (non- } 0 \text { observations): } \\
37.96 \%\end{array}$ \\
\hline Engineering sciences & $\begin{array}{l}\text { Total Grants: } \mathrm{N}=117 \\
\text { Non-0 observations: } 27.73 \%\end{array}$ \\
\hline Social sciences & $\begin{array}{l}\text { Total Grants: } \mathrm{N}=164 \\
\text { Non-0 observations: } 21.59 \%\end{array}$ \\
\hline Humanities & $\begin{array}{l}\text { Total Grants: } \mathrm{N}=27 \\
\text { Non-0 observations: } 5.42 \%\end{array}$ \\
\hline Arts and culture & $\begin{array}{l}\text { Total Grants: } \mathrm{N}=25 \\
\text { Non-0 observations: } 4.81 \%\end{array}$ \\
\hline Sport sciences & $\begin{array}{l}\text { Total Grants: } \mathrm{N}=8 \\
\text { Non-0 observations: } 3.03 \%\end{array}$ \\
\hline
\end{tabular}

An observation refers to a faculty-year. If there was no grant awarded in a faculty-year combination, the observation is regarded as a 0-observation. Accordingly, non-0-observations refer to faculty-year combinations where there was at least one successful grant. In the empirical part of the paper, we run analyses on the level of faculties. For the faculties, we are investigating all faculty-year observations are considered

tics). There is also a vector of characteristics of regions $r$ in which university-faculties are located in $\left(R E G_{r, t-3}^{\prime}\right)$. The regional controls are interacted with year dummies $\left(D_{t}\right)$. $^{8}$

The control variables for university and faculty characteristics focus on different organizational, institutional (faculty and university), and external determinants (regional) that may matter for the prevalence of academic entrepreneurship (for an overview, see O'Shea et al. 2005, 2008; Link and Scott 2005; Rasmussen and Borch 2010; Van Looy et al. 2011). We run separate analyses for specific faculties. Thus, there is always only one universityby-year observation. It should be noted that in this particular case, university fixed effects are similar to faculty-university fixed effects. Accordingly, dummy indicators for the different faculties and universities do not apply in this framework.

One crucial control variable at the university level is a dummy variable indicating a Technical University. Technical Universities in Germany are one specific type of HEIs that has consistently been linked with very entrepreneurship-supportive university policy. Since many areas of their research and teaching are traditionally linked very strongly to industry, Technical Universities have been assumed to be more adept at fostering knowledge spillovers and technology commercialization than general universities (Audretsch and Lehmann 2005a).

We also consider controls that describe current and time-varying characteristics of university-faculty structures. In particular, we control for the size of faculties as measured by the sum of faculty members eligible for a start-up grant (students, recent graduates, and academic staff). We also include the share of students among faculty members to account

\footnotetext{
${ }^{8}$ In the regression analyses where these models are implemented, the constitutive terms of the interaction (year dummies and regional characteristics) have to be included because the interaction cannot be reasonably interpreted without doing so (Brambor et al. 2006).
} 
for potential differences in the entrepreneurial propensity within the group of eligible persons. We also control for the size of the EBA department (which includes BSs) within the social science faculty at the respective universities. Unfortunately, information from university statistics does not allow separating the size of EBA and BSs in terms of staff and students. However, it is possible to distinguish the size of EBA departments within social sciences concerning financial budget resources. The relative size of the EBA department might be important for the level of business start-up grants at social science faculties since the entrepreneurial propensity of EBA staff and students is presumably relatively high within social sciences. The relative size of EBA might also play a role for the emergence of entrepreneurial ideas in other faculties due to cross-faculty knowledge flows.

We also exploit information on third-party funding per professor on the faculty level. This measure is the total amount of third-party funding divided by the number of professors at a faculty. Third-party funding per professor is an indicator of the quality of universities (e.g., Fritsch and Aamoucke 2013) and faculties accordingly. It is important to control for quality since previous studies indicate a positive relationship to academic entrepreneurship (Di Gregorio and Shane 2003; Powers and McDougall 2005).

Another potential determinant of university entrepreneurship that we control for is the private sector share among total third-party funding to capture differences in the commercial orientation of research. Unfortunately, this information is only available at the level of universities. Third-party funding per professor and, in particular, the share of funding by the private sector might explain differences in faculty entrepreneurship (e.g., Di Gregorio and Shane 2003; Gulbrandsen and Smeby 2005; O'Shea et al. 2005; Powers and McDougall 2005; Fritsch and Aamoucke 2013). The lack of information on the funding source at the faculty level is a limitation of our analysis.

Next to these university and faculty characteristics, we also control for the distance of faculties to the university's TTO. Accessibility of the TTO may positively influence the emergence of entrepreneurial ideas at the faculty level since TTOs promote entrepreneurial projects (e.g., O'Shea et al. 2005; Lockett and Wright 2005; Clarysse et al. 2011). In contrast to our main variables of interest, though, distance to TTOs captures much different patterns because the TTO is not necessarily providing or transferring project-specific knowledge. ${ }^{9}$

We also consider whether the university was supported via the "excellence initiative" of the German Federal and State governments for the advancement of science and research in the period of observation. Universities receiving funding for their institutional strategy for project-based development of top-level university research are regarded in this paper as "Excellence University." We employ a dummy variable in the analysis to indicate the respective universities. The variable is a reasonable proxy for quality of research which might be related to faculty spin-off activity as already mentioned above.

Entrepreneurial tradition and the historical record of universities in fostering entrepreneurship are essential drivers of entrepreneurial activity of faculties (e.g., Kenney and Goe 2004; O'Shea et al. 2005; Landry et al. 2006; Hsu et al. 2007). Universities experienced with start-up activity are likely to have entrepreneurship-facilitating infrastructures (network initiatives, incubators) in place. As entrepreneurial activity is more common in these

\footnotetext{
9 The link is only accidental if the TTO personnel by chance has experience with the applicant's specific product or with the industry the applicant operates in. Furthermore, providing access to external actors (VC, business angels) does not refer to the kind of within-university knowledge flows that we are interested in.
} 
institutions, entrepreneurial peers are likely to be present. We capture this tradition by a variable indicating whether universities were early adopters of public policy schemes to promote an entrepreneurial culture at universities. To be more precise, participation in the first wave of the EXIST program line (EXIST I) indicates such a tradition. The respective universities were the first ones to have a systematic entrepreneurship promotion program which was initiated in the late 1990s. There might be a long-term effect of these earlier activities on the emergence of entrepreneurial ideas in the observation period from 2007 to 2014. There have been further EXIST program waves that fall into our observation period which may affect the number of start-ups. EXIST participation implies that the technology transfer office (TTO) of the university pursues a clear entrepreneurial strategy. EXIST program participation is captured by binary indicators.

Regional characteristics can play an important role for academic entrepreneurship and the entrepreneurship culture at universities as well (Fini et al. 2011; Fritsch and Aamoucke 2013). The knowledge infrastructure of a region is often cited as a critical factor in determining spin-off activity (Audretsch and Feldman 1996; O'Shea et al. 2005). If a university is geographically close to many firms interested in its research, its scientists may have more opportunities to share and exchange ideas. Moreover, in a region with higher levels of innovative entrepreneurship, an entire network infrastructure of customers, suppliers and employees is likely to be present, lowering the barriers to starting a university spinoff. The regional environment is captured by three dummy variables indicating the degree of agglomeration of the region hosting the university faculties. The degree of agglomeration is a "catch-all" variable for the regional economy since many of the regional variables are highly correlated with population density (stock of knowledge, house prices, etc.). ${ }^{10}$ The degree of agglomeration also captures a selection of students in certain locations since some students and faculty members prefer large cities while others favor smaller places. Apart from that, we control for the start-up rate in knowledge-intensive industries (KIBS + R\&D intensive manufacturing industries) to capture regional differences in the prevalence of high-quality entrepreneurship. This is supposed to be strongly correlated with the entrepreneurial supporting infrastructure (e.g., access to venture capital, business consultancy support) available that might drive the decision to apply for a business start-up grant (e.g., Sorenson and Stuart 2001; Cumming and Fischer 2012). The regional characteristics are measured at the NUTS3 (county)-level.

We also assess dummy variables for the planning region in which universities and faculties are located in order to capture unobserved differences in the broader regional environment and policymaking. Planning regions represent functionally integrated spatial units comparable to labor market areas in the United States. They consist of several NUTS3 regions. Moreover, every German Federal State comprises several planning regions. Therefore, the dummies indirectly capture unobserved differences on the level of Federal States as well. These controls are important since university policymaking is the task of the Federal States in Germany. We interact the regional control variables with year dummies to

\footnotetext{
${ }^{10}$ We use a classification that distinguishes between city regions, urbanized counties, and rural counties. This classification considers the density and centrality of the broader regional environment in which the university is located. This measure is superior to the population density measure on the county level in our context since some universities are located in city counties (Kreisfreie Staedte) which have a higher density. University cities within other counties may have a high density as well which is however not captured by the county-wide density.
} 
capture region-by-year-specific effects (e.g., business cycle) on the level of entrepreneurial activities across university faculties.

A first assessment of the data reveals that the consideration of an array of region-specific effects implies that dummy controls for the participation in EXIST programs that are supposed to foster an entrepreneurial culture at universities are perfectly collinear. That is, the controls for regional conditions perfectly absorb differences concerning entrepreneurial tradition and culture across universities and regions.

One issue in the context of our empirical setting is that socialist policies in the former German Democratic Republic (GDR) affected university structures and urban planning (e.g., Connelly 2000; Andrusz et al. 1996; Ott 2001). We have no firm idea of how these patterns confound with our prime mechanism; but to err on the side of caution, we present models with and without post-socialist East Germany. Many university faculties in East Germany underwent a significant renovation in the 1990s/early 2000s. This development makes it more likely that business schools were deliberately placed close to highly entrepreneurial science departments since programs/initiatives fostering university entrepreneurship started in the late 1990s as well.

The use of an array of control variables for capturing specific difference across faculties, universities, and regions reduces a potential omitted variable bias. However, it does not address the issue of reverse causality, namely, that the prevalence of entrepreneurial activities explains differences in the location and proximity of faculties. To dispel such concerns, we also employ a 2 SLS approach. The first stage of this approach reads as follows:

$$
\widehat{P R O X \_B} S_{f u, t}=\alpha+\beta * U N I \_A G E_{f u}+X_{f u, t-3}^{\prime} * \gamma+\varepsilon_{f u, r, t-3}
$$

In this equation, we predict values for our proximity measure $\left(\widehat{P R O X \_B} S_{f u, t}\right)$. It is the variation in proximity that is due to the age of the university a faculty belongs to $\left(U N I \_A G E_{f u}\right)$ (see Sect. 4.2.2 and "Appendix B" for details on the choice of instrument). Age is calculated by subtracting the founding year from the year 2007. Please note that university age is also time-invariant. However, the estimation of (2) yields time-varying predicted values for the proximity measure when including time-varying control variables. The vector $X_{f u, t-3}^{\prime}$ reflects the entire set of control variables and region-by-year interactions as in Eq. (1). Determining the founding year was in most cases straightforward. There have been some peculiarities which are documented in the notes of Table 6 in the Appendix. This table also lists the founding years of the universities in our final sample.

Finally, the variation in proximity that is due to the age of universities $\left(\widehat{P R O X}_{f}\right)$ is used in the second stage to explain differences across faculties concerning the emergence of entrepreneurial ideas. The second stage relationship reads as follows:

$$
\operatorname{EXIST}_{f u, t}=\alpha+\beta * \widehat{P R O X \_B} S_{f u, t}+X_{f u, t-3}^{\prime} * \gamma+\varepsilon_{f u, r, t-3}
$$

\section{Results}

\subsection{Cross-faculty knowledge flows and the emergence of entrepreneurial ideas}

The main variable of interest in our models is the distance to the local business school (BS) in walking minutes. We employ log-transformed values of distance in order to rule out that 
major discontinuities in the distance distribution drive our results. ${ }^{11}$ Results are illustrated in Table 2. The model in column I only considers regional characteristics and whether the university is a Technical University which represents a university-fixed effect. The regional fixed effects are interacted with year dummies. Column II and III add control variables for university and faculty characteristics as discussed in the previous section. Column II includes East and West German universities. In column III the sample is restricted to universities in West Germany in order to account for any influences of socialist policies in the former GDR.

Distance to BSs is negatively associated with the emergence of entrepreneurial ideas in natural sciences across German universities while there is no relationship for engineering sciences (Table 2). This difference might have to do with the higher relevance of applied knowledge in engineering. Thus, it might be easier to develop entrepreneurial ideas without knowledge spillovers from BSs as compared to natural sciences. The insignificant findings might also be driven by the lower variability of the distance measure (Table 9). However, the change in the sign of the coefficient across specifications suggests that there is no stable negative relationship between distance and the prevalence of start-up grants in engineering.

The size of the coefficient estimates in the models for natural science is relatively small which comes as no surprise given the low overall number of entrepreneurial projects. An increase in distance by 10 percent on average (approximately: 20 walking minutes) ${ }^{12}$ implies a drop in the EXIST rate by 0.9 units. This is approximately 1 start-up grant per 1000 faculty members. The effect is larger for the sample restricted to West Germany. An increase in distance by 10 percent implies a drop in the EXIST rate by 2.4 units. Running a separate analysis for East German universities (incl. Berlin) reveals that there is no relationship between distance to BSs and the emergence of start-up grants. As aforementioned, this could be explained by socialist legacy effects like a lacking entrepreneurial culture among universities on average. Another obvious reason could be that the variation for the average distance to BSs is lower across East German universities (Table 9). ${ }^{13}$

Tables 11 and 12 show the coefficients for control variables. Notably, distance to TTO is positively related to the EXIST rate for natural sciences. This pattern could be driven by multicollinearity with distance to BSs, but in a model excluding the distance to BS measure, distance to TTO is still positively related to entrepreneurial activity (Table 10). ${ }^{14}$ One explanation for this somewhat puzzling finding is that researchers might be hesitant to contact the TTO if it is too close to their faculty. By approaching the TTO nearby, it could be more easily noticed by their peers that they consider a start-up which they may have wanted to keep secret. On the other hand, contacts to people from BSs are less obviously interpretable as attempts to start a company. Another plausible reason is that universities that value entrepreneurial activities choose to place the TTO in a central administration building (i.e., near the office of the University President) to emphasize its importance, but that these locations are farther from the faculties. Our data show indeed that the distance between natural science

\footnotetext{
11 Kernel density estimates for the distance between faculties before and after log-transformation is shown in Fig. 1.

12 The lowest walking distance is $2 \mathrm{~min}$, the longest is 209 minutes Accordingly, 1 percent in walking distance translates into ca. 2 minutes in walking distance. Due to the skewed distribution of walking distances non-log-transformed values yield no meaningful regression results.

13 The regression results can be obtained upon request.

14 For natural sciences, the correlation between distance to TTO and distance to BS is $r=-0.13$ in the East sample. For the West sample, it is $r=0.72$. For engineering, it is $r=-0.12$ in the East sample and $r=0.82$ in the West sample, respectively.
} 
Table 2 Cross-faculty spillovers BS to natural and engineering sciences (Baseline OLS)

\begin{tabular}{lllllll}
\hline Dep var: EXIST rate & I & II & III & IV & V & VI \\
& All & All & West & All & All & West \\
Controls variables & No & Yes & Yes & No & Yes & Yes \\
& Panel A: Natural sciences & & Panel B: Engineering sciences \\
\hline Distance to BS (log) & $-0.0929 * *$ & $-0.0917 * *$ & $-0.248 * * *$ & -0.0154 & $0.370 * *$ & -0.181 \\
& $(0.0366)$ & $(0.0352)$ & $(0.0874)$ & $(0.0713)$ & $(0.142)$ & $(0.860)$ \\
Observations & 408 & 408 & 312 & 168 & 168 & 104 \\
$\mathrm{R}^{2}$ & 0.385 & 0.403 & 0.525 & 0.299 & 0.360 & 0.381 \\
\hline
\end{tabular}

Significance levels: $* * * P<0.01, * * P<0.05, * P<0.1$

Clustered robust standard errors in parentheses (cluster: university). The models of Panel B include the same variables like those in Panel A. Constant and coefficients for control variables are not shown for brevity. Full models are provided in the Appendix (Tables 11 and 12)

faculties and TTOs is higher at universities that participated in the first wave of the EXIST program line (EXIST I). These universities were early adopters of public policy schemes to promote an entrepreneurial culture at universities. The average distance of TTOs to natural science departments is 35 walking minutes while it is only $19 \mathrm{~min}$ for other universities. The entrepreneurial tradition of EXIST I universities may also imply higher social and cognitive proximity between the TTO and faculty members that compensates for lack of geographical proximity. Similarly, universities that have no such entrepreneurial tradition but put the promotion of entrepreneurship on the agenda recently may strategically place their TTOs in close geographic proximity to natural science departments to compensate for an initially lacking social and cognitive proximity with respect to entrepreneurial orientation. Indeed, the average distance between TTOs and natural science faculties is only 14 walking minutes for universities that participated only in later EXIST program lines. ${ }^{15}$ Finally, if a university has already an entrepreneurial tradition, there might also be a stronger entrepreneurial orientation and practical experience at the faculty level making it less reliable on the TTO to initiate and facilitate entrepreneurial processes. Therefore, geographic proximity may be less important as well at these universities.

\section{IV analysis}

\subsection{The issue of reverse causality}

A concern could be that the results in Table 2 might suffer from endogeneity if BSs and other faculty buildings were "strategically" placed close to each other in order to promote cross-faculty spillover and entrepreneurship. Therefore, OLS estimates on the effect of distance to BSs on entrepreneurship in other faculties might upward bias the coefficient estimates. This pattern should be relatively unlikely, however, since the "third mission" is a relatively new function that universities assume (Etzkowitz 2000, 2003). Therefore,

\footnotetext{
15 An assessment inasmuch there are differences in social and cognitive proximity across universities requires an in-depth qualitative analysis that is beyond the scope of this paper (i.e., interviews with TTO staff and faculty members).
} 
fostering cross-faculty knowledge spillovers should have played less of a role at the time when universities were founded. Nevertheless, in order to assuage remaining concerns, we run instrumental variables regressions as a robustness check to identify the causal effect of proximity between faculties on the emergence of entrepreneurial ideas. We focus on entrepreneurial projects within natural sciences since the OLS estimates indicate that distance to BSs plays a vital role in these faculties only.

To overcome the reverse causality issue that entrepreneurial potential of faculties might determine the distance to other faculties, we use the age of universities as an instrument for proximity in a 2 SLS setting. Our identification strategy relies on the idea that universities founded in recent times are more likely to have all university buildings near to each other since they were built up at the same time. By contrast, the location of faculty buildings of older universities, like those founded in medieval times, is more likely to be sprawled. One reason for this is the increasing breadth of university curricula throughout centuries which is reflected, for example, by the emergence of natural science faculties and the expansion of tertiary education in the 20th century. New faculties at old universities were not necessarily located in proximity to already existing facilities due to idiosyncratic historical city developments constraining opportunities for co-location, especially if the new faculties required some space for laboratories, equipment, etc., like in the natural sciences (for a more detailed line of argumentation, see "Appendix B"). After presenting the IV results, we will show that the age of universities is not related to their entrepreneurial and commercial orientation which assuages concerns regarding the validity of this instrument.

\subsection{IV results}

We employ the log-transformed value of age in our main specification. ${ }^{16}$ Table 3 reports first- and second stage regression results. The structure of models I to III follows those in Table 2. The results indicate that there is a positive relationship between university age and proximity of natural science faculties to BSs. The younger the university, the shorter is the walking distance between respective university facilities. An increase in university age by 10 percent changes the distance of natural science faculties to BSs by between 3.8 and 6.4 percent (walking distance: ca. 7.5-13 min).

The first stages F-statistics have sufficiently high values (Stock et al. 2002) suggesting the relevance of age as an instrument. The results of the second stage estimations are shown in column IV to VI. Proximity to BSs that is due to the age of universities has a positive and significant effect on the level of entrepreneurial activities in natural sciences. ${ }^{17}$ In the analysis that is restricted to West Germany, an increase in walking distance by 10 percent (walking distance: ca. $20 \mathrm{~min}$ ) implies a drop of approximately 0.3 start-up grant per 1000 faculty members.

\footnotetext{
${ }^{16}$ Kernel density estimates for university age before and after log-transformation is shown in Fig. 2. The results resemble those of Table 2 when using the non-transformed age (not reported). The distribution is smoothed with and without log-transformation. We also stick to the log-transformed value of the distance measure in order to interpret the change in distance that is due to age as elasticity (log-log model in the first stage estimation).

17 The explained variance $\left(\mathrm{R}^{2}\right)$ in the models is very high due to including planning region dummies as controls for regional characteristics. Using state dummies instead reduces the $\mathrm{R}^{2}$ to values around 0.6 to 0.7 (not reported).
} 
There is only a weakly significant 2 SLS relationship in the sample including East German natural science faculties when controlling for university and faculty characteristics. Note that the IV results indicate that university age explains differences in proximity between natural sciences and BSs in East Germany as well. However, proximity that is due age seems to be unrelated to entrepreneurship at East German universities. This is in line with OLS results for East Germany reported earlier that could be attributed to lower variation in our distance measure.

The results for the full model for West Germany are robust when bootstrapping the standard errors (see Panel A of Table 15). We also employed bootstrapped standard errors for robustness checks discussed in Sect. 4.3. The results of the IV analysis and the single OLS regression are also not sensitive when measuring region and year effects separately instead of interacting them (see Table 16). The results are also significant for the full sample including East German universities.

In a further assessment, we allow for functional flexibility of the age measure to rule out that our identification strategy is affected by an arbitrary specification of the instrument. So, we use a binary indicator for age which assumes the value of 1 if a university was founded after 1945. Our results remain robust and thus do not appear to be driven by the functional form of the instrument (Table 17). The results show a significant second stage effect for East and West German universities. This suggests that universities founded in the GDR explain the insignificant second stage when employing the continuous age instrument.

Table 18 shows the reduced-form relationship between university age and entrepreneurial activities. Again, the structure of the models follows those in Table 2. A significant relationship between the instrument and the outcome variable in the reduced form in conjunction with a strong relationship between the instrument and instrumented variable in the first-stage regression indicates the presence of a causal relationship. The results in Table 18 reveal a robust relationship between university age and the emergence of entrepreneurial ideas for the sample of West German universities. Using the binary marker indicating whether a university was founded before 1945 yields a significant relationship for the full sample as well.

The results of the reduced-form estimates should not be interpreted as an indication that age has a direct effect on entrepreneurship levels (other than via proximity between natural science faculties and BSs). The next section explicitly deals with the exclusion restriction.

The coefficient estimates for the proximity measure in column VI of Table 3 resemble the one for the OLS estimates in Table 2. They are slightly larger, but there are no severe biases in the coefficient estimates after instrumenting the proximity measure. Hence, our baseline OLS results are not suffering from serious endogeneity problems. As previously argued, endogeneity might be not a particularly strong issue if we assume that location decisions are in most cases determined many decades before the period of analysis and before universities increased their activities in technology transfer. This might hold particularly for older universities. Against this background, a good robustness check is to exclude, for example, universities aged less than 30 years in the baseline OLS regression. This exercise also circumvents the problem that cities, where a university had been recently created, are probably more dynamic and entrepreneurial than the average. This may be less true for cities where a university had been created in last centuries, especially since cities that were dynamic in last centuries are not necessarily dynamic today. The respective models are presented in the Appendix (Table 19) and reveal a robust relationship between distance to BS and the EXIST rate in natural sciences. 
Table 3 Cross-faculty spillovers to natural sciences: IV regressions

\begin{tabular}{lllllll}
\hline & I & II & III & IV & V & VI \\
& All & All & West & All & All & West \\
Controls variables & No & Yes & Yes & No & Yes & Yes \\
& First stage: Dep Var: Distance to BS & Second stage: Dep Var: EXIST rate \\
\hline Age of university $(\log )$ & $0.382 * * *$ & $0.681 * * *$ & $0.506 * * *$ & - & - & - \\
& $(0.123)$ & $(0.0836)$ & $(0.0183)$ & - & - & - \\
Distance to BS $(\log )$ & - & - & - & $-0.165 * *$ & $-0.0926 *$ & $-0.301 * * *$ \\
(IV: Age of university $(\log ))$ & - & - & - & $(0.0654)$ & $(0.0482)$ & $(0.0948)$ \\
Observations & 408 & 408 & 312 & 408 & 408 & 312 \\
$\mathrm{R}^{2}$ & 0.981 & 0.993 & 0.999 & 0.363 & 0.388 & 0.521 \\
First stage F-Statistics & $9.54 * * *$ & $65.24 * * *$ & $746.02 * * *$ & - & - & - \\
\hline
\end{tabular}

Significance levels: $* * * P<0.01, * * P<0.05, * P<0.1$

Clustered robust standard errors in parentheses (cluster: university). Constant and coefficients for control variables are not shown for brevity. Full models can be found in the Appendix (Tables 13 and 14)

We repeated the IV analysis also for engineering sciences to explore whether the insignificant results found in the OLS analysis are eventually due to potential endogeneity issues. However, the results confirm the baseline OLS estimations (Table 20). As expected, the first stage relationship shows that age is also positively related to distances between faculties of engineering and BSs. However, the second stage regression shows that there is no relationship between distance to BS and the emergence of business ideas in engineering. Therefore, in the following section on further robustness checks, we focus primarily on natural sciences. We will report results from OLS regression but also on IV estimates to address potential endogeneity concerns in the modified specifications even though the findings of this section suggest that endogeneity plays a minor role.

\subsection{University age and "taste for entrepreneurship": empirical analyses concerning IV validity}

The credibility of the instrumental variables approach relies on the validity of the instrument. Accordingly, the instrument should not have any influence on the outcome variable other than via the instrumented variable. In the present study, this would be violated if university age has a direct influence on the level of entrepreneurial activities at faculties. University age could be related to the "taste for entrepreneurship." In the following, we show analyses that rule out that there is such a relationship.

The first main concern in this regard is that more traditional universities might have a lower commercial orientation and therefore less entrepreneurship (e.g., Audretsch and Lehmann 2005b). It can be noted, though, that the two-stage relationship in our analysis remains robust when controlling for the share of private sector third-party funding (as an indicator of a university's industry engagement). The second main concern is that age could also affect the number of start-ups by faculty members directly, for instance, because older universities are more established and better able to attract more talented researchers. A measure of such quality is the third-party funding by professor which we also control for in the analysis. 
To assuage these two reasonable concerns, we regress the likelihood of having participated in the EXIST program on the age of universities. As previously mentioned, the EXIST program supports entrepreneurial activities at universities. University age should not be related to the likelihood of being an EXIST university. Please note that every university can apply for an EXIST start-up grant. Participation in the structural EXIST program is not an alternative measure for EXIST start-up grants.

We run logit regressions including the same independent variables as in the previous analyses. As can be seen in Table 4, there is no relationship between university age and university engagement in entrepreneurship support policies. We run a similar analysis with the private sector share of third-party funding as the dependent variable and include the other independent variables used in the previous analyses on the right-hand side of the model. There is also no relationship of age with this indicator for commercial orientation (Table 5). Finally, we adjust third-party funding per professor, which indicates quality, by multiplying with the private sector share of third-party funding, which captures entrepreneurial orientation. There is also no meaningful relationship of age with this indicator. These analyses dispel the two main concerns namely that university age is related to quality and "taste for entrepreneurship."

Finally, we also regress the residuals of the OLS estimates of the models of Table 2 on the instrument to see whether age is uncorrelated with any potential but unobserved determinant of university entrepreneurship that is captured by the residuals. The additional analysis shows that there is no such correlation (Table 21).

\subsection{Robustness checks}

We conducted several robustness checks that confirm our main findings. For example, we excluded universities that participated in EXIST programs over the entire observation period and those that did so before the observation period. As previously mentioned, an earlier participation indicated the presence of an entrepreneurial tradition and a historical record of universities in fostering entrepreneurship. Please note that binary indicators for participation are perfectly collinear with the region-by-year interactions in the main models which are therefore implicitly controlled for. When excluding the respective universities, the negative relationship between distance to BSs and academic entrepreneurship is confirmed (Table 22). ${ }^{18}$ In another specification, we exclude campus universities with very high proximity between natural science faculties and BSs. Similarly, we disregarded small and large faculties in terms of faculty members (Table 23). ${ }^{19}$

We also checked whether observation years with extremely high EXIST rates in certain universities drive our findings. To this end, we excluded the upper 1 percent of the EXIST rate distribution. In further models, we also excluded observations without any EXIST grant to rule out that the skewed distribution of EXIST grants determined our baseline results. The case number is much reduced in the latter specification because there was no approved EXIST grant in 61 percent of all faculty-year observations for natural sciences (Table 24). Throughout all alternative model specifications, our results remain robust and

\footnotetext{
${ }_{18}$ In these models, the case number is too low to apply an IV approach with the same variables as in the OLS regression.

${ }^{19}$ For the definition of campus universities as well as small and large faculties, see notes of this table in the Appendix.
} 
Table 4 Age of universities and engagement in fostering entrepreneurial activities (Logit): analysis for universities with natural science faculty

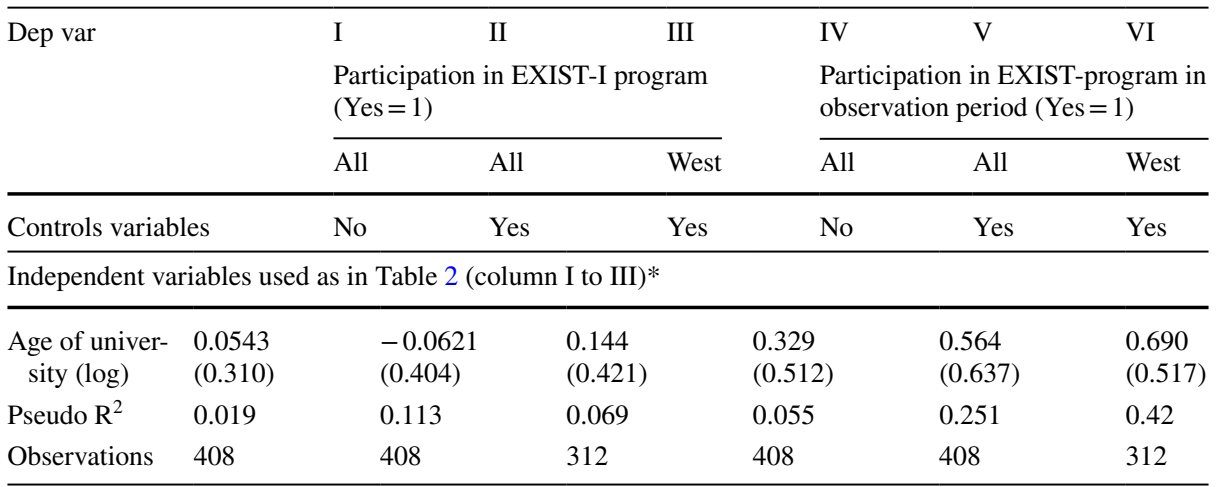

Significance levels: $* * * P<0.01, * * P<0.05, * P<0.1$

Clustered robust standard errors in parentheses (cluster: university). Coefficients for control variables and constant are not shown for brevity. ${ }^{*}$ The planning region and region type dummies were not included since observations would be dropped due to perfect prediction in the models. For the same reason the models include year dummies instead of region type-by-year dummies. In model II dummies for Technical and Excellence universities are not included due to perfect prediction

Table 5 Age of universities, success, and commercial orientation (OLS): Analysis for universities with natural science faculty

\begin{tabular}{|c|c|c|c|c|c|c|}
\hline \multirow[t]{2}{*}{ Dep var: } & I & II & III & IV & V & VI \\
\hline & \multicolumn{3}{|c|}{$\begin{array}{l}\text { Private sector share of third-party } \\
\text { funding }\end{array}$} & \multicolumn{3}{|c|}{$\begin{array}{l}\text { Third-party funding per professor (adj. } \\
\text { for level of third-party funding) }\end{array}$} \\
\hline \multirow[t]{2}{*}{ Controls variables } & All & All & West & All & All & West \\
\hline & $\mathrm{N}$ & $\mathrm{Y}$ & $\mathrm{Y}$ & $\mathrm{N}$ & $\mathrm{Y}$ & $\mathrm{Y}$ \\
\hline \multirow[t]{2}{*}{ Age of university (log) } & $-0.0320 * * *$ & 0.00308 & 0.00923 & $0.00337 * *$ & 0.00247 & 0.00375 \\
\hline & $(0.00504)$ & $(0.0121)$ & $(0.0121)$ & $(0.00163)$ & $(0.00230)$ & $(0.00283)$ \\
\hline Pseudo $\mathrm{R}^{2}$ & 408 & 408 & 312 & 408 & 408 & 312 \\
\hline Observations & 0.799 & 0.810 & 0.830 & 0.850 & 0.852 & 0.869 \\
\hline
\end{tabular}

Significance levels: $* * * P<0.01, * * P<0.05, * P<0.1$

Clustered robust standard errors in parentheses (cluster: university). Coefficients for control variables and constant are not shown for brevity

thus do not appear to be driven by specific types of universities, outliers, or by selection into entrepreneurship promotion programs.

As a further check, the number of EXIST start-up grants instead of the EXIST rate (i.e., number of start-up grants over eligible faculty member) is employed as an alternative outcome measure. The second stage results are in line with the main results. One difference is that there is also a significant 2SLS relationship in the full model including East German natural science faculties. Concerning effect size, an increase in distance to BSs by 1 percent reduces the number of grants by 1 (Table 25). 
We also add the number of start-up grants from BSs before calculating the EXIST rate. By this, we consider that start-up grants where natural science and BS staff have been involved (directly and indirectly) could have been assigned to BSs. The OLS regression and the IV 2 SLS relationship between university age, proximity, and the prevalence of start-up grants resemble the main results in this specification. ${ }^{20}$ Interestingly distance to natural science is not significant when restricting the EXIST rate to start-up grants from BSs only; a modification where potential knowledge flows to natural sciences are neglected (Table 26). ${ }^{21}$ We did a similar analysis for engineering sciences. That is, we add the number of start-up grants from BSs before calculating the EXIST rate in engineering, and we also restrict the EXIST rate to start-up grants from BSs in universities hosting an engineering faculty. This additional exercise confirms again that distance between BSs and engineering does not matter for the emergence of entrepreneurial ideas (Table 27).

One may object that the findings are an artifact of generally low distances of faculties at certain universities. In order to dispel such concerns, we calculated the distance (in walking minutes) between departments of computer sciences and other natural science departments. Browsing the entrepreneurial projects that are supported by an EXIST start-up grant shows that the grand majority of the developed products or the business models (distribution channels etc.) are heavily relying on the increasing importance of information and communication technologies (ICT). Therefore, one could argue that distance to the department of computer sciences should play an important role for the emergence of entrepreneurial ideas. However, the analysis reveals no significant relationship between faculty proximity and the EXIST rate for the West German sample. Thus, the findings on proximity to BSs are not coinciding with results on proximity to other potentially entrepreneurship-promoting university facilities. This pattern also suggests that the distance to "managerial" and "commercial" knowledge is important for the actual emergence of entrepreneurial ideas. ${ }^{22}$ In further placebo analyses, we checked whether the distance to the faculty of sports sciences and faculty of arts mattered. We expect that distance to these faculties should not influence the prevalence of entrepreneurial projects in the natural sciences. This is confirmed empirically (Table 28).

\footnotetext{
${ }^{20}$ Faculty characteristics in this model are based on separate values for natural sciences and EBA. Since there is only information on faculty characteristics of Social Sciences in general, EBA values are obtained by multiplying the share of EBA within Social Sciences, in terms of spending, with the respective values of faculty characteristics of Social Sciences.

21 Please note that this analysis has some caveats. The first issue with this assessment is that we do not have information on the number of business school students and faculty members. There is only aggregate data for staff and students in the social sciences (incl. business schools). Moreover, there is no distinction between economics and business administration in the data. To obtain a rough number for members of business schools, we multiplied the number of university members in social science with the joint financial budget share of economics and business administration within social sciences. The faculty control variables are also only available at the social science faculty level.

22 It should be noted that there is a negative distance effect for the full sample including East German universities. We do not have a firm explanation why distance to computer science is more important than distance to BS when considering East German universities as well. It might be explained by university-specific renovation activities in East Germany in the 1990s/early 2000s.
} 


\section{Concluding remarks}

This study contributes to the literature on university entrepreneurship by investigating the emergence of entrepreneurial ideas at the level of university faculties. This is a novel approach which provides insights into the role of university structures for entrepreneurship and an assessment of cross-faculty spillovers, i.e. a positive influence of proximity of certain faculties on the level of entrepreneurial ideas at other faculties. In particular, we were interested in the role of proximity to business schools (BSs) for the emergence of entrepreneurial ideas in natural science and engineering. The analysis was done by utilizing information on the number of successful start-up grant applications across German university faculties for the years 2007 and 2014.

Our results demonstrate that the level of entrepreneurial activities in natural science faculties is positively affected by proximity to BSs. The larger the distance between university facilities of natural sciences and local BSs, the lower is the magnitude of entrepreneurial ideas emerging out of natural sciences. To overcome the reverse causality issue that entrepreneurial potential of faculties may determine the distance to other faculties, we assess variation in proximity that is due to the age of universities. We conducted robustness checks that confirmed the main findings. The cross-faculty effects between BSs and natural sciences that we find suggest the presence of knowledge spillovers within universities that lead to the commercialization of research and knowledge via entrepreneurship. Against this background, our paper adds a new perspective to the knowledge spillover theory of entrepreneurship (e.g., Acs et al. 2009; Audretsch et al. 2006). Furthermore, it contributes to the literature on social network formation in the university context (e.g., Sacerdote 2001; Zimmerman 2003; Mayer and Puller 2008; Marmaros and Sacerdote 2006).

We do not find similar results for the distance between engineering and BSs and also not for the distance between natural science and engineering to the TTO. We offer reasonable explanations for these patterns. In a nutshell, the applied character of knowledge in engineering does not necessarily require knowledge input on commercialization opportunities from BSs. If a TTO is too close to a faculty, potential entrepreneurs might dare to approach its staff because their peers easily notice that they consider a start-up which they do not want to disclose. Another potential explanation is that universities that value entrepreneurial activities choose to place the TTO in a central administration building (i.e., near the office of the University President) to emphasize its importance without considering that these places are eventually far away from entrepreneurshipfacilitating faculties. Placebo analyses suggest that it is the distance to the BS-specific knowledge, not the distance to other faculties in general, that matter. Altogether, the findings reveal a general underlying mechanism namely that technological knowledge of a less applied character, such as in natural sciences, requires proximity to managerial and commercial knowledge input to emerge into entrepreneurial projects.

One data limitation is that we cannot identify the channel through which proximity-based cross-faculty spillovers between natural sciences and BSs are working since access to personal information of start-up grant holders is severely limited. It can be interdisciplinary team formation which is a direct channel, or it can be indirect general social interaction on the university level. In this respect, potential entrepreneurs, for example, can draw on local expertise from university peers in other faculties. We 
also have no information on other forms of cross-faculty proximity (e.g., social, cognitive, institutional) that may induce spillovers. Seminal studies in the geographic proximity and knowledge spillover literature (e.g., Saxenian 1994; Storper and Venables 2004) show that proximity often works in conjuncture with something else, be it cultural or organizational arrangements. Therefore, disentangling direct and indirect channels as well as incorporating other forms of proximity is warranted in future research. Another limitation is that there is no publicly available information on the number of failed applications for start-up grants. Furthermore, we do not know whether the application succeeded in terms of creating and growing a venture. Exploring the latter and determining success are complex issues and come along with many difficulties since track recording these ventures is hampered by restricted data access and privacy concerns. It is nevertheless an avenue for further research. One particularly interesting approach would be an assessment of the evolution of entrepreneurial competencies in spin-off ventures and venture success (e.g., Wennberg et al. 2011, Rasmussen et al. 2014) against the background of the specific cross-faculty spillovers that we found.

An important avenue for future research is analyzing the role of university facilities other than BSs for fostering cross-faculty knowledge spillovers. Informal knowledge exchange can also be expected from social interactions with departments and faculties other than BSs. Potential academic entrepreneurs may recognize the social and societal relevance of their research from interacting with the faculties of political science and sociology; through casual encounters with members of the law department they might get into contact with experts in patent law; peers from the faculty of culture and arts may help out with expertise in (product) design. Furthermore, apart from geographical proximity other proximity dimensions (e.g., Boschma 2005; Rivera et al. 2010) should be part of the analysis.

The findings of this study imply that policy initiatives aimed at sharpening the focus of universities at the cost of faculty diversity may be detrimental to the technology transfer potential of universities (at least regarding commercializing knowledge via entrepreneurship). The finding that distance between faculties matters for the emergence of entrepreneurial ideas is also informative for the eventual architectural redesigning of universities in the future. Universities with an entrepreneurial mission that are planning to invest in new office and floor space are well-advised to promote proximity between certain faculty buildings. There are certainly cases where such internal relocations are not feasible due to budget constraints or because abandoning old faculty buildings is not sustainable. In such cases, universities should think about measures to increase social and cognitive proximity between faculties (i.e., joint lectures and seminars for engineers and management students; business meets science days) to promote cross-faculty spillover that facilitate entrepreneurship. The digitalization of universities can foster such processes due to enhanced opportunities for internal communication that compensates for lack of geographic proximity. Due to these implications and the novel findings, we deliberately advocate for a much more fine-grained assessment of university entrepreneurship, for instance, at the faculty level, as we do. This research should also consider forms of proximity other than geographical and focus on the spillover channels to gain further interesting insights on knowledge spillovers within universities.

Open Access This article is distributed under the terms of the Creative Commons Attribution 4.0 International License (http://creativecommons.org/licenses/by/4.0/), which permits unrestricted use, distribution, and reproduction in any medium, provided you give appropriate credit to the original author(s) and the source, provide a link to the Creative Commons license, and indicate if changes were made. 


\section{Appendix}

\section{Data cleaning}

An assessment of cross-faculty effects makes only sense for universities with at least two faculties in the city hosting the university. For this reason, we did not consider the small number of private German universities which are specialized in one subject only. Private universities made up of a negligible low 14 EXIST start-up grants (1.2 percent of all startup grants) in the observation period 2007 to 2014. Another specific group of universities that we did not consider are universities of public administration (Verwaltungshochschulen), universities of the armed forces, and parochial HEIs since they have no technology transfer focus. Non-surprisingly no start-up grants have been assigned to these institutions. Public universities that are highly specialized in one main subject only and had no crossfaculty spillover by definition are not considered in the analysis as well. This group comprises art colleges and conservatories but also some other special types of universities. ${ }^{23}$ Such institutions received 11 start-up grants in total. Due to similar patterns universities of applied sciences (UAS) are not suited for the analysis as well. Most UAS have separate campuses in different cities, often with only one faculty per campus. If campus sites are based in different cities or counties, there cannot be any local cross-faculty spillovers by definition. ${ }^{24}$ Moreover, information on the executing unit of the start-up grant is missing for many UAS. Neglecting UAS faculties from the main analysis implies that we lose 19 percent of all EXIST start-up grants. On the other hand, this reflects that the bulk share of science-based business ideas is generated within universities. On the faculty level, we had to exclude medical faculties because it is difficult to distinguish structural characteristics of medical departments from university hospitals with the dataset at hand. ${ }^{25}$

In total, 778 EXIST start-up grants have been assigned to the universities remaining in the sample $(\mathrm{N}=69)$. This is the full sample of universities of interest based on conceptual reasons mentioned above. Unfortunately, there are missing values for some faculty-year observations. We dropped all faculties of a university when there was at least one missing value for the respective faculty between 2007 and 2014. This came along with the loss of 7 start-up grants. We further had to drop two universities (University of Duisburg-Essen and University of Erlangen-Nuremberg) which have two different campus sites at two different cities. The University Statistics database does not allow to consistently assigning information on structure to the different locations. There is no start-up grant assigned to the faculty-year observations for these universities. Information is also missing for the Technical University of Berlin for all its faculties in 2008. Dropping the observations for this university comes along with neglecting 55 EXIST start-up grants. Furthermore, in 10 universities the application procedure for EXIST start-up grants was coordinated via a central service institution dealing with technology transfer (e.g., Career Center; TTO). For these universities we are not able to assign start-up grants to faculties (74 start-up grants).

The sample attrition due to centralized grant applications should be rather a minor issue. It is reasonable to assume that the decision to centralize grant applications at technology

\footnotetext{
23 A list of the excluded higher education institutions can be obtained upon request.

24 We also dropped smaller units of faculties of non-UAS institutions if they are based in totally different counties than the county where the main part of the university is based.

25 We also dropped faculties of veterinary science as well as for agriculture and nutrition because the number of such faculties is extremely low. An analysis makes no sense.
} 
transfer institutions has to do with proximity of faculties. Such centralization of entrepreneurial projects makes sense where the average distances of all faculties to the central institution is low. At the same time the decision to centralize grant applications suggests that the university is interested in a track record of its entrepreneurial activities and centralized synergy effects which indicate emphasis on the entrepreneurial function of universities. Thus, it is likely that universities with a centralized institution coordinating the application process for EXIST start-up grants may have relatively many entrepreneurial activities and a relatively high proximity between faculties. ${ }^{26}$ Thus, excluding these universities may rather induce a downward than an upward bias with respect to estimating the effect of proximity on faculty entrepreneurship. The loss of start-up grants due to dropping the Technical University of Berlin which is a campus university with low proximity between faculties and which accounts for one of the highest shares of start-up grants should rather lead to a downward bias.

\section{University age and distance between faculties: extended line of argumentation and confirmative observations}

Investigating the role of spatial distance between faculties for the emergence of university entrepreneurship comes along with endogeneity concerns. It could be argued that spatial distance is endogenous to a strategy of university administrations and public authorities to encourage specific cross-faculty communication. This would appear in the data when specific faculties within a university are co-located for the purpose of encouraging close collaboration (e.g., natural science departments and BSs), while others are not. To circumvent this issue, in our analysis we make use of exogenous variation in proximity between departments and university scientists. A recent study by Catalini (2015) uses asbestos removal in university offices at medical and scientific complex Paris Jussieu as an exogenous shock to communication patterns. He finds that changing co-location patterns due to this measure affected scientific output. This identification strategy relies on exploiting a change in the legislation that affected where people were placed within universities. In a similar vein, we focus on historically-determined exogenous variation with respect to the placing of entire faculties within cities hosting universities. We rely on an instrumental variable approach which uses the age of universities as an instrument for distance between faculties to dispel endogeneity concerns. The idea behind this identification strategy is straightforward. Changes in the breadth of university curricula and the growing demand for tertiary education over the course of centuries came along with the formation of new faculties and faculty buildings that were not necessarily located in proximity to already existing facilities due to idiosyncratic historical city development constraining opportunities for co-location.

This can be exemplified by reviewing the history of university foundations in Germany which we exploit in this paper. The first medieval universities emerged after the end of the Papal schism in 1386 with the University of Heidelberg opening in the very same year (for details, see Cantoni and Yuchtman 2014). The University of Heidelberg is a case in point with regard to our line of argumentation. While several faculties in humanities are based

\footnotetext{
${ }^{26}$ Mean comparison tests on the university level show indeed that universities with centralized grant applications are significantly more likely to be campus universities. There is at least no significant difference with respect to the level of entrepreneurship activity as compared to the remaining universities. Finally, comparing campus universities with centralized application procedures to those without such a system shows no differences with regard to the prevalence of entrepreneurial projects.
} 
in the historical old town, natural sciences that required some space, for example for laboratories, equipment etc. are mainly concentrated on a campus-like site at the periphery of the city that was built after 1945 due to capacity problems at the historical location of the university. Another example is the Technical University of Munich. It was founded in 1868 by the Bavarian King Ludwig II. The historical main site in downtown Munich was heavily destroyed in World War II and rebuild afterwards. At the same time, a second campus for natural sciences was established in the suburb of Garching while several social science departments are still based in down town Munich.

These examples suggest that especially natural science faculties are likely to be located further away from city centers where historical sites of universities are based. Furthermore, universities founded after World War II have been often built as single campus on Greenfield sites. While historical universities had to develop further sites in order to cope with the unforeseen and unparalleled demand shock with regard to tertiary education after World War II, the location and size of new universities could be aligned with this demand right from the beginning. The decision to start a university after 1945 was made by the Federal States (Laender) and the main motivation was to release existing universities and provide equally distributed possibilities for higher education across space while the foundation of historical universities was mainly due to idiosyncratic reasons (for examples, see Noseleit and Slavtchev 2010).

Using age as instrument for distance overcomes the issue of "strategic" co-location of faculties in order to foster cross-faculty spillovers. It is quite unlikely that technology transfer has been a determinant of location of historical university buildings in pre-industrial times. Carlsson et al. (2009) describe medieval universities as places where utility or economic knowledge played no role since it was regarded rather as a skill than knowledge. Accordingly, the curriculum consisted of Greek and Latin classics and was focused on the study of the Bible. The art of reading, writing, rhetoric, and logic have been important fields while ability and utility played a minor role. Similarly, universities main tasks were to collect, codify, and teach general knowledge. Slight changes can be observed throughout industrialization since the late 18th century which saw the foundation of natural science faculties and the first engineering schools and Technical universities which since the midst of the 19th century started to apply science to invent (Drucker 1998, p. 21). In Germany the first higher education institutions with a technical focus were founded in Karlsruhe and Dresden in the early 19th century while the first natural science faculty opened at the University of Tuebingen in 1863. It could be argued that the location of buildings of the new Technical universities could have been driven by the idea to stimulate technology transfer and cross-faculty knowledge spillover. The Technical universities of Karlsruhe and Dresden are indeed among the oldest institutions that can be regarded as campus universities. ${ }^{27}$ For older universities locating new faculties in close proximity may not have been an option due to idiosyncratic historical development of city structures. Altogether, we claim that university age is negatively related to proximity between its faculties.

\footnotetext{
27 The Technical University Karlsruhe was renamed into Karlsruhe Institute of Technology (KIT) and merged with a research center for nuclear energy north of the city. The original university is based on one campus and therefore counted as a campus university in our sample.
} 
Our argument is that university age matters for proximity between faculties due to historical developments since the midst of the 19th century. If this is the dominant mechanism behind the first stage relationship then there should be no systematic relationship between university age and proximity for the sub-sample of universities that were founded prior to 1850. This threshold was chosen since it reflects the approximate take-off of industrialization in Germany (e.g., Becker et al. 2011) and the time since science was increasingly applied for inventing (Drucker 1998, p. 21). It should hence be less likely that prior to this threshold authorities planned to foster cross-faculty spillovers when making location decision for new faculties.

The data reveal that only 3 out of 26 universities of the sub-sample can be regarded as campus universities which have relatively low distances between faculties (see Table 6). ${ }^{28}$ The three exceptions are the Universities of Karlsruhe and Dresden, which are Technical Universities and were found in the early 19th century, and the University of Mainz (founded in 1477) which was closed in the late 18th century due to idiosyncratic historical events and reopened after World War II at a different site. ${ }^{29}$ There is no other campus university founded prior to 1850 implying that pre-industrial universities created the newly emerging faculties at new sites after 1850 rather than next to the historical site which is likely to be due to space constraints. At the same time this pattern shows that there are no pre-industrial universities that did move their entire facilities to a new campus site in modern times apart from the University of Mainz.

As previously mentioned, there was a significant increase in the demand for tertiary education after World War II. Universities founded after 1945 might have been more likely to be built at Greenfield sites yielding a high proximity between faculties in order to cope with the demand while older universities may have had to develop new sites to do so. Table 6 shows indeed that the bulk share of campus universities was founded after 1945. These preliminary observations underline the role of university age for determining proximity between faculties. At the same time, we will also show that the relationship between age and proximity is not a pure "campus university" effect.

\section{Tables appendix}

See Tables 6, 7, 8, 9, 10, 11, 12, 13, 14, 15, 16, 17, 18, 19, 20, 21, 22, 23, 24, 25, 26, 27 and 28 .

\footnotetext{
28 There is no clear-cut definition for campus universities. We define a campus university as a higher education institution where the bulk share of buildings used for the purpose of research and teaching is adjacent to each other. In the main empirical analysis the threshold was an average walking distance of less than 10 minutes between BS and main facilities of natural science faculties.

29 The French revolutionary army invaded the area of Mainz and established the Mainz Republic of 1792 until the Prussians recaptured the region. Due this turmoil the university became more or less dissolved. The faculty of medicine was still active until 1823 and the faculty of theology continued with teaching activities throughout the 19th century. Since the reopening in 1946 the university is based in the remains of anti-aircraft warfare barracks that were built in Nazi times (http://www.uni-mainz.de/universitaet/96_DEU_ HTML.php).
} 
Table 6 University age and distance to business schools

\begin{tabular}{|c|c|c|c|c|}
\hline \multirow[t]{2}{*}{ Name of university } & \multirow{2}{*}{$\begin{array}{l}\text { "Campus } \\
\text { University"(Yes = 1) }\end{array}$} & \multirow[t]{2}{*}{ Founding year } & \multicolumn{2}{|l|}{ Distance to BS } \\
\hline & & & Natural sciences & Engineering sciences \\
\hline $\begin{array}{l}\text { Brandenburgische TU } \\
\text { Cottbus }\end{array}$ & 1 & 1991 & 58.75 & 54.3333 \\
\hline FU Berlin & 1 & 1948 & 38.25 & + \\
\hline $\begin{array}{l}\text { Humboldt-Universität } \\
\text { Berlin }\end{array}$ & 0 & 1809 & 151.333 & + \\
\hline TH Aachen & 0 & 1870 & 15.8571 & 15.25 \\
\hline TU Bergakademie Freiberg & 0 & 1765 & 14 & 15 \\
\hline TU Braunschweig & 0 & 1745 & 7.66667 & 7.5 \\
\hline TU Chemnitz & 0 & 1836 & 23.5 & 5 \\
\hline TU Clausthal & 0 & 1775 & 14.6 & 15.3333 \\
\hline TU Darmstadt & 0 & 1877 & 18.8333 & 35.1667 \\
\hline TU Dresden & 1 & 1828 & 10.1667 & 34.6667 \\
\hline TU Ilmenau & 1 & 1953 & 16 & 8 \\
\hline TU München & 0 & 1868 & 208.5 & 44.8333 \\
\hline U Bamberg & 0 & 1647 & 16.5 & + \\
\hline U Bayreuth & 1 & 1975 & 2.85714 & 4 \\
\hline U Bielefeld & 1 & 1969 & 1 & + \\
\hline U Bochum & 1 & 1962 & 4.85714 & 9.33333 \\
\hline U Bonn & 0 & 1818 & 27.375 & 23.5 \\
\hline U Bremen & 1 & 1971 & 8.83333 & 13.5 \\
\hline U Dortmund & 1 & 1968 & 15 & 11.5 \\
\hline U Düsseldorf & 1 & 1965 & 3 & + \\
\hline $\begin{array}{l}\text { U Flensburg (PH Flens- } \\
\text { burg) }\end{array}$ & 1 & 1946 & 2 & + \\
\hline U Frankfurt a.M. & 0 & 1914 & 76.625 & + \\
\hline U Freiburg i.Br. & 0 & 1457 & 14.75 & 25 \\
\hline U Gießen & 0 & 1607 & 29.6667 & + \\
\hline U Greifswald & 0 & 1456 & 19.875 & + \\
\hline U Göttingen & 0 & 1734 & 31.2857 & + \\
\hline U Halle in Halle & 0 & 1502 & 43.25 & 46.5 \\
\hline U Hannover & 0 & 1831 & 16.2857 & 33.5714 \\
\hline U Heidelberg & 0 & 1386 & 25.375 & + \\
\hline U Hildesheim & 0 & 1978 & 7.83333 & + \\
\hline U Jena & 0 & 1558 & 8 & 19 \\
\hline U Karlsruhe & 1 & 1825 & 14.7143 & 11 \\
\hline U Kassel in Kassel & 1 & 1970 & 63.6667 & 4.6 \\
\hline U Kiel (auch: PH Kiel) & 0 & 1665 & 8.875 & 32 \\
\hline U Konstanz & 1 & 1966 & 2.4 & + \\
\hline U Köln & 1 & 1919 & 9.66667 & + \\
\hline U Leipzig & 0 & 1409 & 16.125 & + \\
\hline U Lüneburg & 0 & 1946 & 2 & + \\
\hline U Magdeburg & 1 & 1993 & 13.4 & 2.5 \\
\hline U Mainz in Mainz & 1 & 1477 & 8.875 & + \\
\hline U Mannheim & 1 & 1967 & 12 & + \\
\hline
\end{tabular}


Table 6 (continued)

\begin{tabular}{lllll}
\hline Name of university & $\begin{array}{l}\text { "Campus } \\
\text { University"(Yes = 1) }\end{array}$ & Founding year & Distance to BS \\
\cline { 3 - 4 } & & & Natural sciences & Engineering sciences \\
\hline U Marburg & 0 & 1527 & 40.2857 & + \\
U München & 0 & 1826 & 70.7143 & + \\
U Münster & 0 & 1780 & 22.5714 & + \\
U Osnabrück & 0 & 1974 & 26.2 & + \\
U Passau & 1 & 1978 & 4.5 & + \\
U Regensburg & 1 & 1962 & 3 & 20 \\
U Rostock & 0 & 1419 & 15.8333 & 70.25 \\
U Stuttgart & 0 & 1829 & 118.6 & + \\
U Tübingen & 0 & 1477 & 34.25 & 22 \\
U Ulm & 1 & 1967 & 9.8 & + \\
U Würzburg & 0 & 1402 & 39 & 21.75 \\
U-GH Wuppertal & 0 & 1972 & 1.66667 & + \\
\hline
\end{tabular}

One issue is the closure of universities over time. If a university was closed for more than 100 years, the new founding year is used. Universities are counted as campus universities if all major buildings devoted to teaching and research are situated at one site. If only specific facilities are at a distant location then the university is regarded as campus university as well. The Technical University Karlsruhe, for example, was renamed into Karlsruhe Institute of Technology (KIT) and merged with a research center for nuclear energy north of the city. The original university is based on one campus and therefore counted as a campus university in our sample. In two cases (Kassel, Cottbus) some natural science and engineering facilities are not based at the main campus. This explains the high distances to BS

+No natural science (engineering science) faculty at university

Table 7 Definition of main variables. Sources: Federal German University Statistics, "funding catalogue" ("Förderkatalog") of the Federal Ministry of Economy and Technology, Google maps

\begin{tabular}{|c|c|}
\hline Variable & Definition \\
\hline EXIST rate & $\begin{array}{l}\text { Number of EXIST start-up grants/number of students, academic } \\
\text { personnel, and graduates (faculty level) }\end{array}$ \\
\hline Distance to BS & $\begin{array}{l}\text { Average distance in walking minutes of major faculty buildings to the } \\
\text { department of Economics and Business Administration (Source: } \\
\text { Google maps); log-transformed values used in main analysis }\end{array}$ \\
\hline Age of university & $\begin{array}{l}\text { The variable indicates the age in which the university was founded } \\
\text { (Year 2007-Founding Year); log-transformed values used in main } \\
\text { analysis }\end{array}$ \\
\hline Distance to TTO & $\begin{array}{l}\text { Average distance in walking minutes of major faculty buildings to } \\
\text { the Technology Transfer Office (Source: Google maps); log-trans- } \\
\text { formed values used in main analysis }\end{array}$ \\
\hline Faculty Size & $\begin{array}{l}\text { Number of students, academic personnel, and graduates (faculty } \\
\text { level) in } 1000(\log )\end{array}$ \\
\hline Share of students & $\begin{array}{l}\text { Number of students/number of students, academic personnel, and } \\
\text { graduates (faculty level) }\end{array}$ \\
\hline Share of EBA within social sciences & $\begin{array}{l}\text { Size of EBA department within Social Science faculty. Size is } \\
\text { captured by share of university spending due to data constraints } \\
\text { (faculty level) }\end{array}$ \\
\hline Third-party funding per professor & $\begin{array}{l}\text { Sum of third-party funding/Number of professors (in Euro) (faculty } \\
\text { level) }\end{array}$ \\
\hline
\end{tabular}


Table 7 (continued)

\begin{tabular}{ll}
\hline Variable & Definition \\
\hline Share of private Third-party funding & $\begin{array}{c}\text { Share of third-party funding from the private sector/total third-party } \\
\text { funding (university level) } \\
\text { University is a Technische Universität }\end{array}$ \\
$\begin{array}{l}\text { Technical University (Yes }=1) \\
\text { Excellence University (Yes }=1)\end{array}$ & $\begin{array}{l}\text { University was successful in the program line "Institutional strategies } \\
\text { for the project-based development of top-level university research" } \\
\text { of the excellence initiative by the German government for the } \\
\text { advancement of science and research at German universities }\end{array}$ \\
Regional number of start-ups in knowledge-intensive business ser- \\
vices and R\&D-intensive manufacturing industries divided by the \\
regional number of employees (*1000) \\
The county in which the university is based is counted as city region \\
The county in which the university is based is counted as urbanized \\
county \\
Urbanized county $(Y e s=1)$ \\
The county in which the university is based is counted as rural \\
county
\end{tabular}

Table 8 Summary statistics

\begin{tabular}{lccll}
\hline & Mean & S.D. & Min & Max \\
\hline EXIST rate & 0.12 & 0.26 & 0 & 2.93 \\
Distance to BS & 27.13 & 33.05 & 2 & 209.5 \\
Age of university & 212.3 & 192.98 & 14 & 621 \\
Distance to TTO & 24.26 & 24.85 & 1 & 137 \\
Faculty Size (in 1000) (log) & 0.9 & 1.29 & -4.19 & 3.22 \\
Share of students & 0.75 & 0.07 & 0.4 & 0.91 \\
Share of EBA within social sciences & 0.55 & 0.22 & 0.08 & 1 \\
Third-party funding per professor & 0.2 & 0.18 & 0 & 1.07 \\
Share of private Third-party funding & 0.18 & 0.13 & 0 & 0.5 \\
Technical University (Yes =1) & 0.25 & 0.44 & 0 & 1 \\
Excellence university (Yes=1) & 0.15 & 0.36 & 0 & 1 \\
Rate of high quality start-ups & 1.2 & 0.46 & 0.32 & 3.1 \\
City regions (Yes =1) & 0.39 & 0.49 & 0 & 1 \\
Urbanized counties (Yes =1) & 0.41 & 0.49 & 0 & 1 \\
Rural counties (Yes =1) & 0.2 & 0.4 & 0 & 1 \\
\hline
\end{tabular}

Correlation matrix is not shown for brevity but can be obtained upon request 
Table 9 Summary statistics for key variables by faculty

\begin{tabular}{|c|c|c|c|c|}
\hline & Mean & SD & Min & Max \\
\hline \multicolumn{5}{|l|}{ Panel A: Natural science } \\
\hline \multicolumn{5}{|l|}{ Germany } \\
\hline EXIST rate & 0.12 & 0.22 & 0 & 1.46 \\
\hline Average distance to Business School $(\log )$ & 2.79 & 1.06 & 0.69 & 5.34 \\
\hline Average distance to TTO $(\log )$ & 2.67 & 1.02 & 0 & 4.76 \\
\hline \multicolumn{5}{|l|}{ West Germany } \\
\hline EXIST rate & 0.11 & 0.21 & 0 & 1.45 \\
\hline Average distance to Business School (log) & 2.74 & 1.16 & 0.69 & 5.34 \\
\hline Average distance to TTO $(\log )$ & 2.68 & 1.04 & 0 & 4.76 \\
\hline \multicolumn{5}{|l|}{ East Germany } \\
\hline EXIST rate & 0.15 & 0.28 & 0 & 1.46 \\
\hline Average distance to Business School (log) & 2.96 & 0.53 & 2.2 & 4.09 \\
\hline Average distance to TTO $(\log )$ & 2.65 & 0.95 & 0.69 & 3.7 \\
\hline \multicolumn{5}{|l|}{ Panel B: Engineering science } \\
\hline \multicolumn{5}{|l|}{ Germany } \\
\hline EXIST rate & 0.14 & 0.33 & 0 & 2.93 \\
\hline Average distance to Business School (log) & 2.88 & 0.78 & 1.25 & 4.27 \\
\hline Average distance to TTO $(\log )$ & 2.94 & 0.93 & 1.39 & 4.92 \\
\hline \multicolumn{5}{|l|}{ West Germany } \\
\hline EXIST rate & 0.14 & 0.3 & 0 & 1.45 \\
\hline Average distance to Business School (log) & 3.02 & 0.67 & 1.72 & 4.27 \\
\hline Average distance to TTO $(\log )$ & 2.68 & 1.15 & 0 & 4.76 \\
\hline \multicolumn{5}{|l|}{ East Germany } \\
\hline EXIST rate & 0.13 & 0.39 & 0 & 2.93 \\
\hline Average distance to Business School (log) & 2.81 & 0.94 & 1.25 & 4.01 \\
\hline Average distance to TTO $(\log )$ & 2.43 & 1.02 & 0.69 & 3.7 \\
\hline
\end{tabular}

Table 10 Cross-faculty spillovers BS to natural and engineering sciences: sensitivity check for potential multicollinearity between distance measures

\begin{tabular}{lllll}
\hline Dep var: EXIST rate & I & II & III & IV \\
& All & West & All & West \\
Controls variables & Yes & Yes & Yes & Yes \\
& Panel A: Natural Sciences & \multicolumn{2}{l}{$\begin{array}{l}\text { Panel B: Engineering } \\
\text { Sciences }\end{array}$} \\
& & & - & - \\
\hline Distance to BS (log) & - & - & 0.0514 & -0.134 \\
Control: distance to TTO $(\log )$ & $0.0431^{* * *}$ & $0.0507^{* *}$ & $(0.120)$ & $(0.474)$ \\
& $(0.0153)$ & $(0.0189)$ & 168 & 104 \\
Observations & 408 & 312 & 0.307 & 0.352 \\
$\mathrm{R}^{2}$ & 0.383 & 0.506 & &
\end{tabular}

Significance levels: $* * * P<0.01, * * P<0.05, * P<0.1$

Clustered robust standard errors in parentheses (cluster: university). The models of Panel B include the same variables like those in Panel A. Constant and coefficients for control variables are not shown for brevity. Full models can be obtained upon request 
Table 11 Full OLS baseline model natural science (Full model of Panel A of Table 2)

\begin{tabular}{|c|c|c|c|}
\hline Dep var: EXIST rate & $\begin{array}{l}\text { I } \\
\text { All }\end{array}$ & $\begin{array}{l}\text { II } \\
\text { All }\end{array}$ & $\begin{array}{l}\text { IV } \\
\text { West }\end{array}$ \\
\hline Distance to BS (log) & $\begin{array}{l}-0.0933^{* *} \\
(0.0374)\end{array}$ & $\begin{array}{l}-0.0907 * * * \\
(0.0334)\end{array}$ & $\begin{array}{l}-0.248 * * * \\
(0.0878)\end{array}$ \\
\hline Faculty Size & - & $\begin{array}{l}0.0354 \\
(0.0369)\end{array}$ & $\begin{array}{l}0.0279 \\
(0.0393)\end{array}$ \\
\hline Distance to TTO $(\log )$ & - & $\begin{array}{l}0.0474 * * * \\
(0.0160)\end{array}$ & $\begin{array}{l}0.0904 * * * \\
(0.0241)\end{array}$ \\
\hline Share of students & - & $\begin{array}{l}-0.442 \\
(0.694)\end{array}$ & $\begin{array}{l}-1.046 \\
(0.808)\end{array}$ \\
\hline Share of EBA within social sciences & - & $\begin{array}{l}0.179 \\
(0.142)\end{array}$ & $\begin{array}{l}0.159 \\
(0.167)\end{array}$ \\
\hline Third-party funding per professor & - & $\begin{array}{l}-0.0893 \\
(0.208)\end{array}$ & $\begin{array}{l}0.170 \\
(0.203)\end{array}$ \\
\hline Share of private Third-party funding & - & $\begin{array}{l}0.443 \\
(0.275)\end{array}$ & $\begin{array}{l}0.381 \\
(0.259)\end{array}$ \\
\hline Excellence university (Yes = 1) & - & $\begin{array}{l}-0.0208 \\
(0.0358)\end{array}$ & $\begin{array}{l}0.0165 \\
(0.0324)\end{array}$ \\
\hline Technical University (Yes $=1$ ) & $\begin{array}{l}0.247 * * * \\
(0.0452)\end{array}$ & $\begin{array}{l}0.251 * * * \\
(0.0570)\end{array}$ & $\begin{array}{l}0.434 * * * \\
(0.0730)\end{array}$ \\
\hline Region X Year-Effects & $\mathrm{Y}$ & Y & $\mathrm{Y}$ \\
\hline Planning Region Dummies & $\mathrm{Y}$ & $\mathrm{Y}$ & $\mathrm{Y}$ \\
\hline Constant & $\begin{array}{l}0.538 * * * \\
(0.160)\end{array}$ & $\begin{array}{l}0.589 \\
(0.540)\end{array}$ & $\begin{array}{l}0.810 \\
(0.615)\end{array}$ \\
\hline Observations & 408 & 408 & 312 \\
\hline $\mathrm{R}^{2}$ & 0.367 & 0.388 & 0.521 \\
\hline
\end{tabular}

Significance levels: $* * * P<0.01, * * P<0.05, * P<0.1$

Clustered robust standard errors in parentheses (cluster: university). Region X Year-Effects comprise interactions of the year dummies with the rate of high-quality start-ups and dummies for the regional degree of agglomeration (groups: city regions; urbanized counties; rural counties). The constitutive terms for the interaction are included as well 
Table 12 Full OLS baseline model engineering science (Full model of Panel B of Table 2)

\begin{tabular}{|c|c|c|c|}
\hline Dep var: EXIST rate & $\begin{array}{l}\text { IV } \\
\text { All }\end{array}$ & $\begin{array}{l}\text { V } \\
\text { All }\end{array}$ & $\begin{array}{l}\text { VI } \\
\text { West }\end{array}$ \\
\hline Distance to BS (log) & $\begin{array}{l}-0.0130 \\
(0.0824)\end{array}$ & $\begin{array}{l}0.470 * * \\
(0.173)\end{array}$ & $\begin{array}{l}-0.192 \\
(0.152)\end{array}$ \\
\hline Faculty Size & - & $\begin{array}{l}0.383 * * * \\
(0.119)\end{array}$ & $\begin{array}{l}0.0193 \\
(0.381)\end{array}$ \\
\hline Distance to TTO (log) & - & $\begin{array}{l}0.212 * * \\
(0.0901)\end{array}$ & $\begin{array}{l}0.0264 \\
(0.466)\end{array}$ \\
\hline Share of students & - & $\begin{array}{l}-0.00328 \\
(1.387)\end{array}$ & $\begin{array}{l}-0.330 \\
(1.829)\end{array}$ \\
\hline Share of EBA within social sciences & - & $\begin{array}{l}-0.741 \\
(0.519)\end{array}$ & $\begin{array}{l}-0.102 \\
(0.549)\end{array}$ \\
\hline Third-party funding per professor & - & $\begin{array}{l}-0.281 \\
(0.257)\end{array}$ & $\begin{array}{l}0.125 \\
(0.299)\end{array}$ \\
\hline Share of private Third-party funding & - & $\begin{array}{l}0.0886 \\
(0.552)\end{array}$ & $\begin{array}{l}0.836 \\
(0.783)\end{array}$ \\
\hline Excellence university $(\mathrm{Yes}=1)$ & - & $\begin{array}{l}-0.0618 \\
(0.109)\end{array}$ & $\begin{array}{l}0.167 \\
(0.325)\end{array}$ \\
\hline Technical University (Yes $=1$ ) & $\begin{array}{l}0.219 * * * \\
(0.0403)\end{array}$ & $\begin{array}{l}0.604 * \\
(0.323)\end{array}$ & $\begin{array}{l}-0.0514 \\
(0.247)\end{array}$ \\
\hline Region X Year-Effects & $\mathrm{Y}$ & $\mathrm{Y}$ & Y \\
\hline Planning Region Dummies & $\mathrm{Y}$ & $\mathrm{Y}$ & $\mathrm{Y}$ \\
\hline Constant & $\begin{array}{l}0.282 \\
(0.527)\end{array}$ & $\begin{array}{l}-0.532 \\
(1.146)\end{array}$ & $\begin{array}{l}0.552 \\
(2.048)\end{array}$ \\
\hline Observations & 168 & 168 & 104 \\
\hline $\mathrm{R}^{2}$ & 0.261 & 0.327 & 0.352 \\
\hline
\end{tabular}

Significance levels: $* * * P<0.01, * * P<0.05, * P<0.1$

Clustered robust standard errors in parentheses (cluster: university). Region X Year-Effects comprise interactions of the year dummies with the rate of high-quality start-ups and dummies for the regional degree of agglomeration (groups: city regions; urbanized counties; rural counties). The constitutive terms for the interaction are included as well 
Table 13 Baseline model natural science: first stage IV Regression (Full model column I to III, Table 3)

\begin{tabular}{|c|c|c|c|}
\hline Dep var: EXIST rate & $\begin{array}{l}\text { I } \\
\text { All }\end{array}$ & $\begin{array}{l}\text { II } \\
\text { All }\end{array}$ & $\begin{array}{l}\text { III } \\
\text { West }\end{array}$ \\
\hline Age of university (log) & $\begin{array}{l}0.382 * * * \\
(0.123)\end{array}$ & $\begin{array}{l}0.681 * * * \\
(0.0836)\end{array}$ & $\begin{array}{l}0.506 * * * \\
(0.0183)\end{array}$ \\
\hline Faculty Size & - & $\begin{array}{l}-0.376^{* * *} * \\
(0.0631)\end{array}$ & $\begin{array}{l}-0.217 * * * \\
(0.0377)\end{array}$ \\
\hline Distance to TTO $(\log )$ & - & $\begin{array}{l}0.159 * * * \\
(0.0150)\end{array}$ & $\begin{array}{l}0.188 * * * \\
(0.0122)\end{array}$ \\
\hline Share of students & - & $\begin{array}{l}0.974 * * * \\
(0.336)\end{array}$ & $\begin{array}{l}-0.00571 \\
(0.118)\end{array}$ \\
\hline Share of EBA within social sciences & - & $\begin{array}{l}-0.257 \\
(0.249)\end{array}$ & $\begin{array}{l}0.0635 \\
(0.0683)\end{array}$ \\
\hline Third-party funding per professor & - & $\begin{array}{l}-0.651 * * * \\
(0.229)\end{array}$ & $\begin{array}{l}-0.0543 \\
(0.0449)\end{array}$ \\
\hline Share of private Third-party funding & - & $\begin{array}{l}-0.202 \\
(0.151)\end{array}$ & $\begin{array}{l}0.0841 \\
(0.0733)\end{array}$ \\
\hline Excellence university (Yes $=1$ ) & - & $\begin{array}{l}-0.176^{* * * *} \\
(0.0572)\end{array}$ & $\begin{array}{l}-0.0637 * * \\
(0.0265)\end{array}$ \\
\hline Technical University $(Y e s=1)$ & $\begin{array}{l}0.930 * * * \\
(0.196)\end{array}$ & $\begin{array}{l}1.678 * * * \\
(0.100)\end{array}$ & $\begin{array}{l}1.429 * * * \\
(0.0511)\end{array}$ \\
\hline Region X Year-Effects & $\mathrm{Y}$ & $\mathrm{Y}$ & $\mathrm{Y}$ \\
\hline Planning Region Dummies & $\mathrm{Y}$ & $\mathrm{Y}$ & $\mathrm{Y}$ \\
\hline Constant & $\begin{array}{l}2.650 * * * \\
(0.641)\end{array}$ & $\begin{array}{l}-2.797 * * * \\
(0.614)\end{array}$ & $\begin{array}{l}1.678 * * * \\
(0.126)\end{array}$ \\
\hline Observations & 408 & 408 & 312 \\
\hline $\mathrm{R}^{2}$ & 0.981 & 0.993 & 0.999 \\
\hline
\end{tabular}

Significance levels: $* * * P<0.01, * * P<0.05, * P<0.1$

Clustered robust standard errors in parentheses (cluster: university). Region X Year-Effects comprise interactions of the year dummies with the rate of high-quality start-ups and dummies for the regional degree of agglomeration (groups: city regions; urbanized counties; rural counties). The constitutive terms for the interaction are included as well 
Table 14 Baseline model natural science: second stage of IV Regression (Full model: column IV to VI, Table 3)

\begin{tabular}{|c|c|c|c|}
\hline IV: Age of university (log) & IV & $\mathrm{V}$ & VI \\
\hline Dep var: EXIST rate & All & All & West \\
\hline Distance to BS (log) & $\begin{array}{l}-0.165^{* *} \\
(0.0654)\end{array}$ & $\begin{array}{l}-0.0926^{*} \\
(0.0482)\end{array}$ & $\begin{array}{l}-0.301 \text { *** } \\
(0.0948)\end{array}$ \\
\hline Faculty Size & - & $\begin{array}{l}0.0353 \\
(0.0327)\end{array}$ & $\begin{array}{l}0.0271 \\
(0.0348)\end{array}$ \\
\hline Distance to TTO $(\log )$ & - & $\begin{array}{l}0.0475 * * * \\
(0.0150)\end{array}$ & $\begin{array}{l}0.0988 * * * \\
(0.0231)\end{array}$ \\
\hline Share of students & - & $\begin{array}{l}-0.442 \\
(0.620)\end{array}$ & $\begin{array}{l}-1.143 \\
(0.735)\end{array}$ \\
\hline Share of EBA within social sciences & - & $\begin{array}{l}0.179 \\
(0.124)\end{array}$ & $\begin{array}{l}0.150 \\
(0.142)\end{array}$ \\
\hline Third-party funding per professor & - & $\begin{array}{l}-0.0881 \\
(0.190)\end{array}$ & $\begin{array}{l}0.222 \\
(0.194)\end{array}$ \\
\hline Share of private Third-party funding & - & $\begin{array}{l}0.442 * \\
(0.245)\end{array}$ & $\begin{array}{l}0.388^{*} \\
(0.224)\end{array}$ \\
\hline Excellence university (Yes $=1$ ) & - & $\begin{array}{l}-0.0212 \\
(0.0346)\end{array}$ & $\begin{array}{l}0.0208 \\
(0.0289)\end{array}$ \\
\hline Technical University (Yes = 1) & $\begin{array}{l}0.305 * * * \\
(0.0614)\end{array}$ & $\begin{array}{l}0.253 * * * \\
(0.0578)\end{array}$ & $\begin{array}{l}0.489 * * * \\
(0.0810)\end{array}$ \\
\hline Region X Year-Effects & $\mathrm{Y}$ & $\mathrm{Y}$ & $\mathrm{Y}$ \\
\hline Planning Region Dummies & $\mathrm{Y}$ & $\mathrm{Y}$ & $\mathrm{Y}$ \\
\hline Constant & $\begin{array}{l}0.904 * * * \\
(0.309)\end{array}$ & $\begin{array}{l}0.531 \\
(0.524)\end{array}$ & $\begin{array}{l}1.662 * * \\
(0.748)\end{array}$ \\
\hline Observations & 408 & 408 & 312 \\
\hline $\mathrm{R}^{2}$ & 0.363 & 0.388 & 0.521 \\
\hline
\end{tabular}

Significance levels: $* * * P<0.01, * * P<0.05, * P<0.1$

Clustered robust standard errors in parentheses (cluster: university). Region X Year-Effects comprise interactions of the year dummies with the rate of high-quality start-ups and dummies for the regional degree of agglomeration (groups: city regions; urbanized counties; rural counties). The constitutive terms for the interaction are included as well 
Table 15 Main IV regressions with bootstrapped standard errors

\begin{tabular}{llll}
\hline & I & II & III \\
\hline $\begin{array}{l}\text { Panel A: Table 3: Cross-faculty spillovers to natural sciences: IV regres- } \\
\text { sions }\end{array}$ & & & \\
Distance to BS $(\log )$ & -0.165 & -0.0926 & $-0.301 * *$ \\
(IV: Age of universities $(\log ))$ & $(0.120)$ & $(0.0866)$ & $(0.136)$ \\
N & 408 & 408 & 312
\end{tabular}

Panel B: Table 17: Baseline model natural science: IV Regression with alternative instrument

$\begin{array}{llll}\text { Distance to BS (log) } & -0.143 & -0.235^{*} & -0.309 * * \\ \begin{array}{l}\text { (IV: Foundation of Univer- } \\ \quad \text { sity < Year 1945) }\end{array} & (0.0965) & (0.142) & (0.137) \\ \text { N } & 408 & 408 & 312\end{array}$

Panel C: Table 22: Cross-faculty spillover from BS to natural sciences: checking for potential selection into structural entrepreneurship programs (OLS) (column I to III)

$\begin{array}{llll}\text { Distance to BS }(\log ) & -0.160 * & -0.272 & -0.423^{* *} \\ \text { (IV: Age of universities }(\log )) & (0.0899) & (0.201) & (0.185) \\ \text { N } & 328 & 328 & 256\end{array}$

Panel D: Table 23: Cross-faculty spillover from BS to natural sciences: checking for sensitivity to excl. campus universities and faculties of small and large size (column I to III)

$\begin{array}{llll}\text { Distance to BS }(\log ) & -0.167 & -0.118 & -0.397 * * \\ \text { (IV: Age of universities }(\log )) & (0.122) & (0.0835) & (0.186) \\ \text { N } & 320 & 320 & 224\end{array}$

Panel E: Table 23: Cross-faculty spillover from BS to natural sciences: checking for sensitivity to excl. campus universities and faculties of small and large size (column IV to VI)

$\begin{array}{llll}\text { Distance to BS }(\log ) & -0.209 & -0.161 & -0.398^{* *} \\ \text { (IV: Age of universities }(\log )) & (0.154) & (0.326) & (0.171) \\ \text { N } & 341 & 341 & 253\end{array}$

Panel F: Table 24: Cross-faculty spillover from BS to natural sciences: checking for sensitivity to excluding observations from the upper and the lower part of the EXIST rate distribution (column I to III)

$\begin{array}{llll}\text { Distance to BS }(\log ) & -0.214^{*} & -0.158^{* *} & -0.297 * * \\ \text { (IV: Age of universities }(\log )) & (0.114) & (0.0740) & (0.145) \\ \text { N } & 403 & 403 & 311\end{array}$

Panel G: Table 25: Cross-faculty spillover from BS to natural sciences: checking for sensitivity to employing an alternative dependent variable
Distance to BS (log)
$-0.767$
$-0.930 * *$
$-0.914^{* *}$
(IV: Age of universities $(\log )$ )
(0.481)
(0.450)
(0.432)
$\mathrm{N}$
$408 \quad 408$
312

Panel H: Table 26: Sensitivity of main results to considering EXIST grants from BS: Analysis for natural science faculties

\begin{tabular}{llll} 
Distance to BS $(\log )$ & $-0.0939^{*}$ & -0.0905 & $-0.274^{* *}$ \\
(IV: Age of universities $(\log ))$ & $(0.0571)$ & $(0.0732)$ & $(0.114)$ \\
$\mathrm{N}$ & 408 & 408 & 312 \\
\hline
\end{tabular}

Standard errors in parentheses. $* * * P<0.01$, $* * P<0.05, * P<0.1$. The results are based on 1000 replications. The models shown in column IV to VI of Table 23 are not included because of insufficient observations to compute bootstrap standard errors 


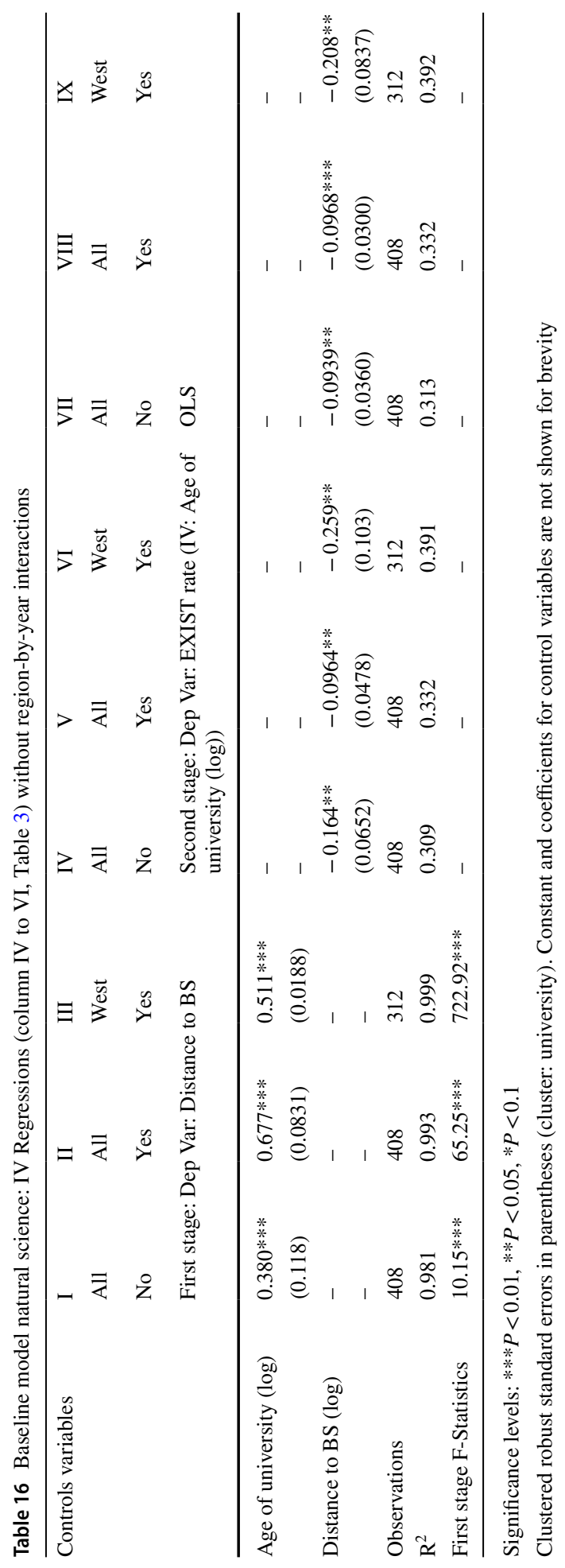




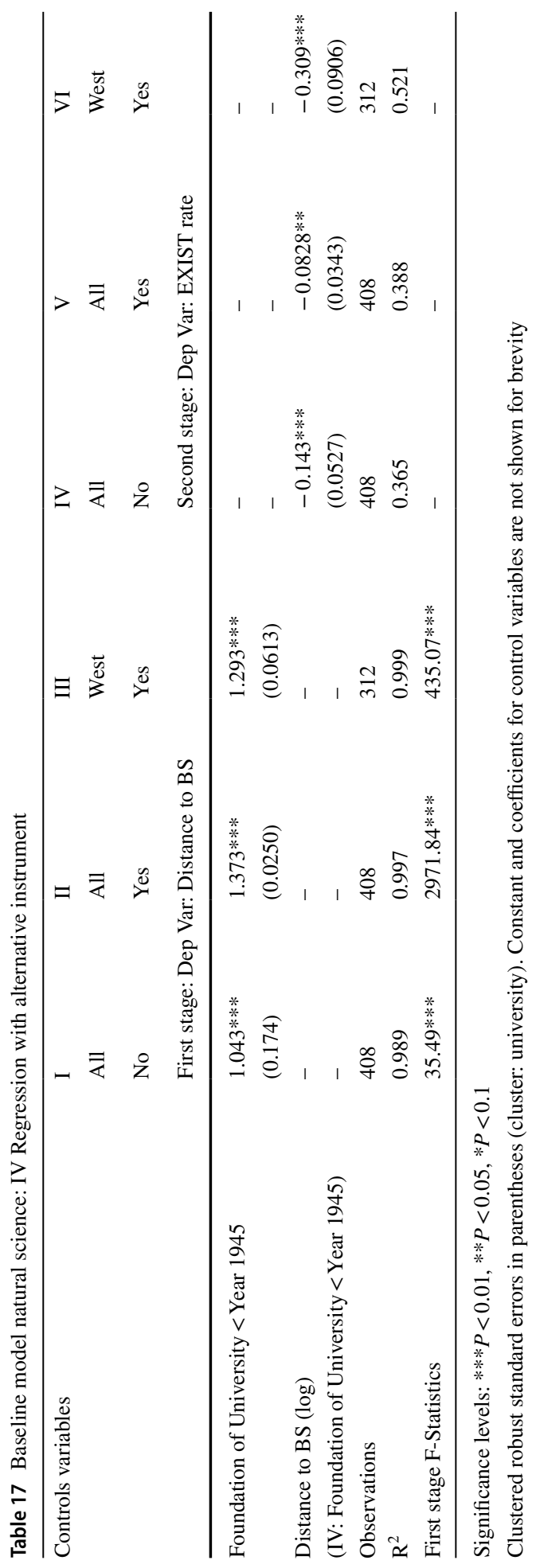


Table 18 Baseline model natural science: reduced form estimates

\begin{tabular}{lllllll}
\hline Dep Var: EXIST rate & I & II & III & IV & V & VI \\
& All & All & West & All & All & West \\
Controls variables & No & Yes & Yes & No & Yes & Yes \\
\hline Age of university (log) & $-0.0630 * * *$ & $-0.0630 *$ & $-0.152 * * *$ & & & \\
& $(0.0165)$ & $(0.0318)$ & $(0.0524)$ & & & \\
Foundation of University & & & & $-0.149 * * *$ & $-0.114 * *$ & $-0.399 * * *$ \\
$<$ Year 1945 & & & & $(0.0371)$ & $(0.0521)$ & $(0.130)$ \\
Observations & 408 & 408 & 312 & 408 & 408 & 312 \\
$\mathrm{R}^{2}$ & 0.368 & 0.387 & 0.525 & 0.370 & 0.386 & 0.526 \\
\hline
\end{tabular}

Significance levels: $* * * P<0.01, * * P<0.05, * P<0.1$

Clustered robust standard errors in parentheses (cluster: university). Coefficients for control variables and constant are not shown for brevity

Table 19 OLS regressions excluding young universities (age less than 30 years in 2007)

\begin{tabular}{lllllll}
\hline Dep var: EXIST rate & I & II & III & IV & V & VI \\
& All & All & West & All & All & West \\
Controls variables & No & Yes & Yes & No & Yes & Yes \\
& Panel A: Natural sciences & & Panel B: Engineering sciences \\
\hline Distance to BS (log) & $-0.0936^{* *}$ & $-0.0936^{* *}$ & $-0.256^{* *}$ & -0.0108 & 0.382 & -0.153 \\
& $(0.0362)$ & $(0.0350)$ & $(0.0957)$ & $(0.0909)$ & $(0.242)$ & $(0.978)$ \\
Observations & 376 & 376 & 296 & 152 & 152 & 104 \\
$\mathrm{R}^{2}$ & 0.454 & 0.473 & 0.524 & 0.273 & 0.334 & 0.352 \\
\hline
\end{tabular}

Significance levels: $* * * P<0.01, * * P<0.05, * P<0.1$

Clustered robust standard errors in parentheses (cluster: university). The models of Panel B include the same variables like those in Panel A. Constant and coefficients for control variables are not shown for brevity 
Table 20 Baseline model engineering sciences: IV Regression

\begin{tabular}{lllllll}
\hline Controls variables & I & II & III & IV & V & VI \\
& All & All & West & All & All & West \\
& No & Yes & Yes & No & Yes & Yes \\
& First stage: Dep Var: Distance to BS & Second stage: Dep Var: EXIST \\
& & & & rate & & \\
\hline Age of university (log) & $0.366^{* *}$ & $0.364^{* * *}$ & $0.605^{* * *}$ & - & - & - \\
& $(0.156)$ & $(0.128)$ & $(0.0686)$ & - & - & - \\
Distance to BS (log) & - & - & - & 0.0509 & 0.0475 & -0.0161 \\
(IV: Age of university (log)) & - & - & - & $(0.0374)$ & $(0.0361)$ & $(0.0398)$ \\
Observations & 168 & 168 & 104 & 168 & 168 & 104 \\
$R^{2}$ & 0.357 & 0.612 & 0.903 & 0.210 & 0.241 & 0.295 \\
First stage F-Statistics & $5.27 * * *$ & $7.68^{* * *}$ & $72.48^{* * *}$ & - & - & -
\end{tabular}

Significance levels: $* * * P<0.01, * * P<0.05, * P<0.1$

Clustered robust standard errors in parentheses (cluster: university). Constant and coefficients for control variables are not shown for brevity. It is not controlled for planning regions because in model II to IV the case number is too low to apply the IV approach. Including the planning regions in model I turn the coefficient for age to weakly significant. Full models can be obtained upon request

Table 21 Regressing the residuals of the OLS model (Table 2) on the instrument for natural sciences

\begin{tabular}{llll}
\hline $\begin{array}{l}\text { Dep var: Residual of model } \\
\text { I to III, Table 2 }\end{array}$ & All & II & III \\
Controls variables & No & Yes & West \\
\hline Age of university (log) & -0.0273 & -0.00127 & Yes \\
\hline Observations & $(0.0213)$ & $(0.0368)$ & $(0.0547)$ \\
$\mathrm{R}^{2}$ & 408 & 408 & 312 \\
\hline
\end{tabular}

Significance levels: $* * * P<0.01, * * P<0.05, * P<0.1$

Clustered robust standard errors in parentheses (cluster: university). Constant and coefficients for control variables are not shown for brevity

There is also no significant relationship between age and the residuals in bivariate regressions including only the age as explanatory variable 
Table 22 Cross-faculty spillover from BS to natural sciences: checking for potential selection into structural entrepreneurship programs (OLS)

\begin{tabular}{llll}
\hline Dep var: EXIST rate & I & II & III \\
& All & All & West \\
Controls variables & No & Yes & Yes \\
\hline Panel A: OLS regression & & & \\
Distance to BS (log) & $-0.137 * * *$ & $-0.142 * * *$ & $-0.423 * *$ \\
& $(0.0397)$ & $(0.0251)$ & $(0.171)$ \\
Observations & 328 & 328 & 256 \\
$\mathrm{R}^{2}$ & 0.384 & 0.416 & 0.598 \\
Panel B: IV second stage regression (IV: Age of university $(\log ))$ & \\
Distance to BS (log) & $-0.160^{* * *}$ & $-0.272^{* *}$ & $-0.423 * *$ \\
& $(0.0450)$ & $(0.135)$ & $(0.145)$ \\
Observations & 328 & 328 & 256 \\
$\mathrm{R}^{2}$ & 0.384 & 0.416 & 0.598 \\
First stage F-Statistics & $120.35^{* * *}$ & $43306.5 * * *$ & - \\
\hline
\end{tabular}

Significance levels: $* * * P<0.01, * * P<0.05, * P<0.1$

Clustered robust standard errors in parentheses (cluster: university). The models of Panel B include the same variables like those in Panel A. Constant and coefficients for control variables are not shown for brevity. The first stage F-Statistics cannot be displayed in model III because the matrix of first-stage estimates has missing values

Table 23 Cross-faculty spillover from BS to natural sciences: checking for sensitivity to excl. campus universities and faculties of small and large size

\begin{tabular}{lllllll}
\hline Dep Var: EXIST rate & I & II & III & IV & V & VI \\
& All & All & West & All & All & West \\
Controls variables & No & Yes & Yes & No & Yes & Yes \\
& Excl. "campus“universities & & Excl. small and large faculties & \\
\hline
\end{tabular}

Panel A: OLS regression

$\begin{array}{lllllll}\text { Distance to BS }(\log ) & -0.113^{* * *} & -0.106^{* * *} & -0.393 * * & -0.152^{* * *} & -0.165^{* * *} & -0.307 * * \\ & (0.0383) & (0.0255) & (0.168) & (0.0456) & (0.0339) & (0.131) \\ \text { Observations } & 320 & 320 & 224 & 341 & 341 & 253 \\ \mathrm{R}^{2} & 0.405 & 0.417 & 0.592 & 0.434 & 0.450 & 0.539\end{array}$

Panel B: IV second stage regression (IV: Age of university $(\log )$ )

\begin{tabular}{lllllll} 
Distance to BS $(\log )$ & $-0.167^{* * *}$ & $-0.118^{* * *}$ & $-0.397 * * *$ & $-0.209^{* * *}$ & $-0.161^{* *}$ & $-0.398^{* * *}$ \\
& $(0.0601)$ & $(0.0431)$ & $(0.140)$ & $(0.0586)$ & $(0.0662)$ & $(0.143)$ \\
Observations & 320 & 320 & 224 & 341 & 341 & 253 \\
$\mathrm{R}^{2}$ & 0.403 & 0.416 & 0.592 & 0.432 & 0.450 & 0.537 \\
First stage F-Statistics & $9.51^{* * *}$ & $93.63^{* * *}$ & $33407.1 * * *$ & $14.88^{* * *}$ & $40.74 * * *$ & $227.23 * * *$ \\
\hline
\end{tabular}

Significance levels: $* * * P<0.01, * * P<0.05, * P<0.1$

Clustered robust standard errors in parentheses (cluster: university). Coefficients for control variables and constant are not shown for brevity. Full models and first stage regressions of the IV approach can be obtained upon request. Universities with a walking distance of less than 10 min between BS and natural science faculty is regarded as campus university and excluded in model I to IV. The definition deviates from the one used in Table 6. Here a campus university is defined as a university where all major buildings devoted to teaching and research are situated at one site which comprises large campuses where distance between BS and natural sciences is larger than $10 \mathrm{~min}$. In two cases (Kassel, Cottbus) some natural science facilities are not based at the main campus. The models in column V to VIII disregard faculties with less than 1000 and more than 10,000 EXISTeligible faculty members. 9 percent of the observations were larger, 7 percent were smaller than these thresholds 
Table 24 Cross-faculty spillover from BS to natural sciences: checking for sensitivity to excluding observations from the upper and the lower part of the EXIST rate distribution

\begin{tabular}{|c|c|c|c|c|c|c|}
\hline \multirow[t]{2}{*}{ Dep Var: EXIST rate } & I & II & III & IV & V & VI \\
\hline & All & All & West & All & All & West \\
\hline \multirow[t]{2}{*}{ Controls variables } & No & Yes & Yes & No & Yes & Yes \\
\hline & \multicolumn{3}{|c|}{$\begin{array}{l}\text { Excl. Upper } 1 \% \text { of EXIST rate distribu- } \\
\text { tion }\end{array}$} & \multicolumn{3}{|c|}{$\begin{array}{l}\text { Excl. Upper } 1 \% \text { of EXIST rate distri- } \\
\text { bution and obs without EXIST grant }\end{array}$} \\
\hline \multicolumn{7}{|l|}{ Panel A: OLS regression } \\
\hline Distance to BS $(\log )$ & $\begin{array}{l}-0.116^{* * *} \\
(0.0320)\end{array}$ & $\begin{array}{l}-0.125 * * * \\
(0.0233)\end{array}$ & $\begin{array}{l}-0.236 * * * \\
(0.0867)\end{array}$ & $\begin{array}{l}-0.170 * * * \\
(0.0533)\end{array}$ & $\begin{array}{l}-0.171 * * * \\
(0.0360)\end{array}$ & $\begin{array}{l}-0.323 * * * \\
(0.114)\end{array}$ \\
\hline Observations & 403 & 403 & 311 & 148 & 148 & 110 \\
\hline $\mathrm{R}^{2}$ & 0.458 & 0.477 & 0.537 & 0.766 & 0.840 & 0.914 \\
\hline \multicolumn{7}{|c|}{ Panel B: IV second stage regression (IV: Age of university $(\log )$ ) } \\
\hline Distance to BS $(\log )$ & $\begin{array}{l}-0.214 * * * \\
(0.0411)\end{array}$ & $\begin{array}{l}-0.158 * * * \\
(0.0431)\end{array}$ & $\begin{array}{l}-0.297 * * * \\
(0.0939)\end{array}$ & $\begin{array}{l}-0.338^{* * *} \\
(0.118)\end{array}$ & $\begin{array}{l}-0.173 * * * \\
(0.0264)\end{array}$ & $\begin{array}{l}-0.283 * * * \\
(0.0723)\end{array}$ \\
\hline Observations & 403 & 403 & 311 & 148 & 148 & 110 \\
\hline $\mathrm{R}^{2}$ & 0.449 & 0.476 & 0.535 & 0.698 & 0.840 & 0.914 \\
\hline First stage F-Statistics & $10.49 * * *$ & $63.56^{* * * *}$ & $747.43^{* * * *}$ & $5.99 * * *$ & $213.53 * * *$ & $632.22 * * *$ \\
\hline
\end{tabular}

Significance levels: $* * * P<0.01, * * P<0.05, * P<0.1$

Clustered robust standard errors in parentheses (cluster: university). Coefficients for control variables and constant are not shown for brevity. Full models and first stage regressions of the IV approach can be obtained upon request

Table 25 Cross-faculty spillover from BS to natural sciences: checking for sensitivity to employing an alternative dependent variable

\begin{tabular}{llll}
\hline Dep Var: Number of EXIST grants & I & III & IV \\
& All & All & West \\
Controls variables & No & Yes & Yes \\
\hline Panel A: OLS regression & & & \\
Distance to BS (log) & $-1.047^{* * *}$ & $-0.985^{* * *}$ & $-0.794^{* * *}$ \\
& $(0.324)$ & $(0.123)$ & $(0.268)$ \\
Observations & 408 & 408 & 312 \\
$\mathrm{R}^{2}$ & 0.707 & 0.724 & 0.796 \\
Panel B: IV second stage regression (IV: Age of university $(\log ))$ & & \\
Distance to BS (log) & $-1.122^{* * *}$ & $-0.930^{* * *}$ & $-0.914^{* * *}$ \\
& $(0.325)$ & $(0.126)$ & $(0.252)$ \\
Observations & 408 & 408 & 312 \\
$\mathrm{R}^{2}$ & 0.707 & 0.724 & 0.796 \\
First stage F-Statistics & $21.46^{* * *}$ & $65.24^{* * *}$ & $746.02^{* * * *}$ \\
\hline
\end{tabular}

Significance levels: $* * * P<0.01, * * P<0.05, * P<0.1$

Clustered robust standard errors in parentheses (cluster: university). Coefficients for control variables and constant are not shown for brevity. Full models and first stage regressions of the IV approach can be obtained upon request 
Table 26 Sensitivity of main results to considering EXIST grants from BS: analysis for natural science faculties

\begin{tabular}{|c|c|c|c|c|c|c|}
\hline \multirow[t]{2}{*}{ Dep Var: EXIST rate } & I & II & III & IV & $\mathrm{V}$ & VI \\
\hline & All & All & West & All & All & West \\
\hline \multirow[t]{2}{*}{ Controls variables } & No & Yes & Yes & No & Yes & Yes \\
\hline & \multicolumn{3}{|c|}{$\begin{array}{l}\text { EXIST Grants: Business } \\
\text { Schools + Natural Sciences }\end{array}$} & \multicolumn{3}{|c|}{$\begin{array}{l}\text { EXIST Grants: Business } \\
\text { Schools }\end{array}$} \\
\hline \multicolumn{7}{|l|}{ Panel A: OLS regression } \\
\hline $\begin{array}{l}\text { Distance BS-Natural Science } \\
(\log )\end{array}$ & $\begin{array}{l}-0.0749 * * * \\
(0.0215)\end{array}$ & $\begin{array}{l}-0.0819^{* *} \\
(0.0307)\end{array}$ & $\begin{array}{l}-0.242 * * * \\
(0.0824)\end{array}$ & $\begin{array}{l}-0.0700 \\
(0.0797)\end{array}$ & $\begin{array}{l}-0.121 \\
(0.133)\end{array}$ & $\begin{array}{l}-0.556 \\
(0.379)\end{array}$ \\
\hline Observations & 408 & 408 & 312 & 408 & 408 & 312 \\
\hline $\mathrm{R}^{2}$ & 0.423 & 0.431 & 0.566 & 0.392 & 0.449 & 0.518 \\
\hline \multicolumn{7}{|c|}{ Panel B: IV second stage regression (IV: Age of university $(\log )$ ) } \\
\hline $\begin{array}{l}\text { Distance BS-Natural Science } \\
\quad(\log )\end{array}$ & $\begin{array}{l}-0.0939 * * * \\
(0.0285)\end{array}$ & $\begin{array}{l}-0.0905^{* *} \\
(0.0445)\end{array}$ & $\begin{array}{l}-0.274 * * * \\
(0.0654)\end{array}$ & $\begin{array}{l}-0.0925 \\
(0.0725)\end{array}$ & $\begin{array}{l}-0.157 \\
(0.221)\end{array}$ & $\begin{array}{l}-0.386 \\
(0.285)\end{array}$ \\
\hline Observations & 408 & 408 & 312 & 408 & 408 & 320 \\
\hline $\mathrm{R}^{2}$ & 0.423 & 0.431 & 0.566 & 0.36 & 0.429 & 0.47 \\
\hline First stage F-Statistics & $9.54 * * *$ & 25.16 *** & $365.50 * * *$ & $9.54 * * *$ & $8.62^{* * * *}$ & $11.02^{* * *}$ \\
\hline
\end{tabular}

Significance levels: $* * * P<0.01, * * P<0.05, * P<0.1$

Clustered robust standard errors in parentheses (cluster: university). Coefficients for control variables and constant are not shown for brevity. Full models and first stage regressions of the IV approach can be obtained upon request

Table 27 Sensitivity of main results to considering EXIST grants from BS: analysis for engineering faculties

\begin{tabular}{lllllll}
\hline Dep Var: EXIST rate & I & II & III & IV & V & VI \\
& All & All & West & All & All & West \\
Controls variables & No & Yes & Yes & No & Yes & Yes \\
& $\begin{array}{l}\text { EXIST Grants: Business Schools + Natu- } \\
\text { ral Sciences }\end{array}$ & & & EXIST Grants: Business Schools \\
& & & & & \\
\hline Panel A: OLS regression & & & & & \\
Distance BS-Natural & -0.0343 & $-0.575^{*}$ & $-0.779^{*}$ & 0.0334 & 0.0271 & -0.0885 \\
Science (log) & $(0.0314)$ & $(0.283)$ & $(0.362)$ & $(0.0503)$ & $(0.0686)$ & $(0.132)$ \\
Observations & 168 & 168 & 104 & 168 & 168 & 104 \\
$\mathrm{R}^{2}$ & 0.408 & 0.518 & 0.528 & 0.243 & 0.353 & 0.562 \\
\hline
\end{tabular}

Significance levels: $* * * P<0.01, * * P<0.05, * P<0.1$

Clustered robust standard errors in parentheses (cluster: university). Coefficients for control variables and constant are not shown for brevity. Full models and first stage regressions of the IV approach can be obtained upon request 
Table 28 Placebo analyses: Distance between natural science and other faculties (OLS)

\begin{tabular}{|c|c|c|c|}
\hline \multirow[t]{2}{*}{ Dep var: EXIST rate } & I & III & IV \\
\hline & All & All & West \\
\hline Controls variables & No & Yes & Yes \\
\hline \multicolumn{4}{|c|}{ Panel A: Distance Natural Sciences (excl. computer science)-Computer science } \\
\hline Distance in walking min $(\log )$ & $\begin{array}{l}-0.0322 \\
(0.0243)\end{array}$ & $\begin{array}{l}-0.0362 * * \\
(0.0178)\end{array}$ & $\begin{array}{l}-0.00716 \\
(0.0156)\end{array}$ \\
\hline Observations & 392 & 392 & 296 \\
\hline $\mathrm{R}^{2}$ & 0.383 & 0.403 & 0.558 \\
\hline \multicolumn{4}{|c|}{ Panel B: Distance Natural Sciences-Sport Sciences } \\
\hline Distance in walking min $(\log )$ & $\begin{array}{l}-0.00679 \\
(0.0296)\end{array}$ & $\begin{array}{l}-0.0188 \\
(0.0162)\end{array}$ & $\begin{array}{l}-0.00618 \\
(0.0197)\end{array}$ \\
\hline Observations & 312 & 312 & 248 \\
\hline $\mathrm{R}^{2}$ & 0.422 & 0.431 & 0.430 \\
\hline \multicolumn{4}{|c|}{ Panel C: Distance Natural Sciences-Faculty of Arts } \\
\hline Distance in walking min $(\log )$ & $\begin{array}{l}-0.0690 * * * \\
(0.0184)\end{array}$ & $\begin{array}{l}-0.0225 \\
(0.0276)\end{array}$ & $\begin{array}{l}-0.00881 \\
(0.0255)\end{array}$ \\
\hline Observations & 240 & 240 & 192 \\
\hline $\mathrm{R}^{2}$ & 0.469 & 0.486 & 0.568 \\
\hline
\end{tabular}

Significance levels: $* * * P<0.01, * * P<0.05, * P<0.1$

Clustered robust standard errors in parentheses (cluster: university). The models of Panel B include the same variables like those in Panel A. Constant and coefficients for control variables are not shown for brevity. Full models can be obtained upon request

IV results are not reported because university age turns out to be a poor predictor of average distance between faculties. Computer sciences are often based at the same site like other natural sciences. Faculties of Sports and Arts are much smaller on average than BS. Therefore, history is less of a constraint for colocation

\section{Figures appendix}

See Figs. 1, 2

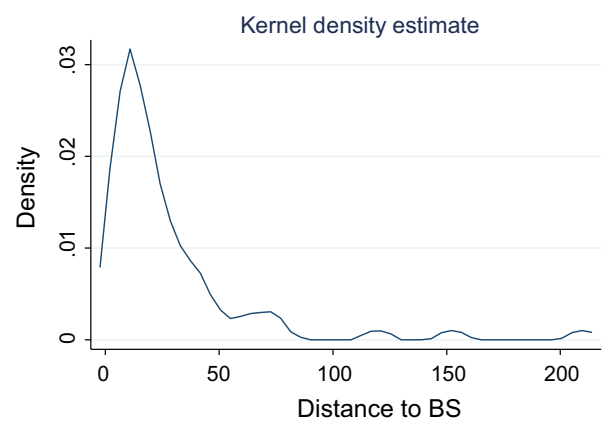

kernel $=$ epanechnikov, bandwidth $=4.3767$

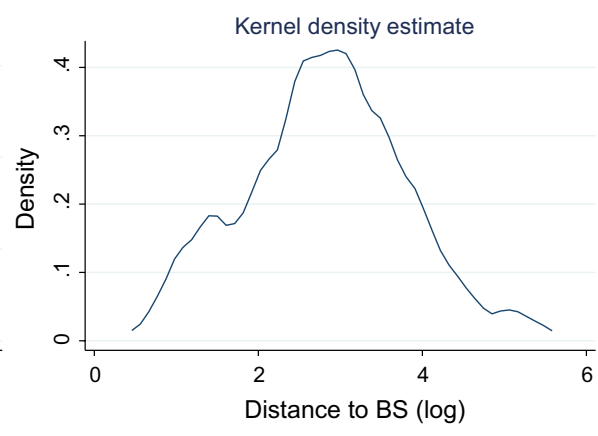

kernel $=$ epanechnikov, bandwidth $=0.2385$

Fig. 1 Density estimates for the distance to BS. The figures refer to all facilities of natural science and engineering science faculties of the final sample. The left-tail in Fig. 1 is due to "campus universities" where the distance is very low 


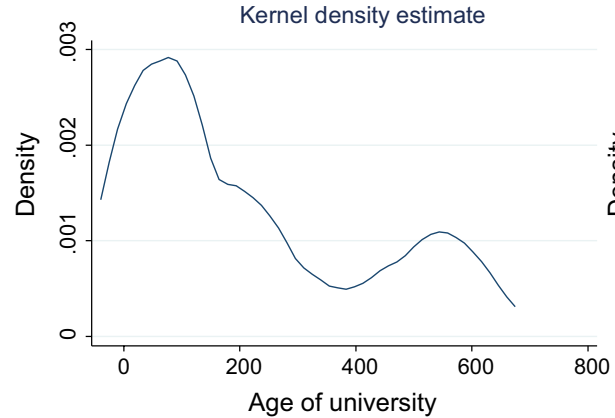

kernel $=$ epanechnikov, bandwidth $=53.8363$

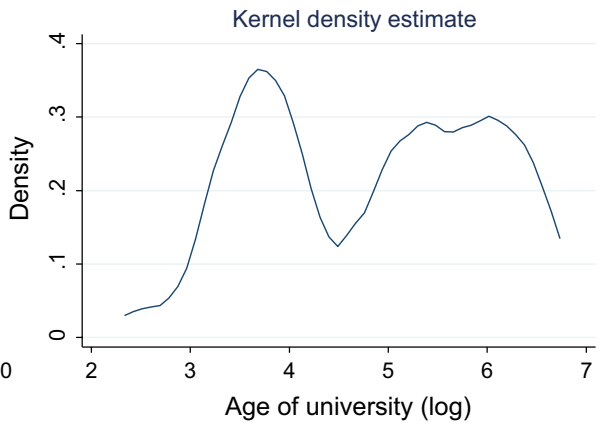

kernel $=$ epanechnikov, bandwidth $=0.3049$

Fig. 2 Density estimates for age of universities. The figures refer to all universities of the final sample. Every university has a natural science faculty. The smaller peak around the age of 600 years (year 1400) is due to the exogenous increase in the founding of universities after the end of the papal schism (see Cantoni and Yuchtman 2014)

\section{References}

Abramovsky, L., Harrison, R., \& Simpson, H. (2007). University research and the location of business R\&D. Economic Journal, 117, C114-C141.

Abramovsky, L., \& Simpson, H. (2011). Geographic proximity and firm-university innovation linkages: Evidence from Great Britain. Journal of Economic Geography, 11, 949-977.

Abreu, M., \& Grinevich, V. (2013). The nature of academic entrepreneurship in the UK: Widening the focus on entrepreneurial activities. Research Policy, 42, 408-422.

Acs, Z. J., Braunerhjelm, P., Audretsch, D. B., \& Carlsson, B. (2009). The knowledge spillover theory of entrepreneurship. Small Business Economics, 32, 15-30.

Adams, J. (2002). Comparative localization of academic and industrial spillovers. Journal of Economic Geography, 2, 253-278.

Agrawal, A., \& Goldfarb, A. (2008). Restructuring research: Communication costs and the democratization of University Innovation. American Economic Review, 98(4), 1578-1590.

Allen, T. (1977). Managing the flow of technology. Cambridge: MIT Press.

Andrusz, G., Harloe, M., \& Szelenyi, I. (1996). Cities after socialism: Urban and regional change and conflict in post-socialist societies. Oxford: Blackwell.

Astebro, T., \& Bazzazian, N. (2011). Universities, entrepreneurship, and local economic development. In M. Fritsch (Ed.), Handbook of research on entrepreneurship and regional development. National and Regional Perspectives (pp. 252-334). Cheltenham: Edward Elgar.

Audretsch, D. B. (2007). The entrepreneurial society. New York: Oxford University Press.

Audretsch, D. B., \& Feldman, M. P. (1996). R\&D spillovers and the geography of innovation and production. American Economic Review, 86, 630-640.

Audretsch, D. B., Keilbach, M., \& Lehmann, E. (2006). Entrepreneurship and economic growth. New York: Oxford University Press.

Audretsch, D. B., \& Lehmann, E. (2005a). Do university policies make a difference? Research Policy, 34, 343-347.

Audretsch, D. B., \& Lehmann, E. (2005b). Does the knowledge spillover theory of entrepreneurship hold for regions? Research Policy, 34, 1191-1202.

Auerswald, P. E. (2007). The simple economics of technology entrepreneurship: Market failure reconsidered. In D. B. Audretsch, I. Grilo, \& R. Thurik (Eds.), Handbook of research on entrepreneurship policy (pp. 18-36). Cheltenham: Edward Elgar.

Autio, E., Kenney, M., Mustar, P., Siegel, D., \& Wright, M. (2014). Entrepreneurial innovation: The importance of context. Research Policy, 43, 1097-1108.

Bae, T. J., Qian, S., Miao, C., \& Fiet, J. O. (2014). The relationship between entrepreneurship education and entrepreneurial intentions: A meta-analytic review. Entrepreneurship Theory and Practice, 38(2), 217-254. 
Bandiera, O., Barankay, I., \& Rasul, I. (2010). Social incentives in the workplace. The Review of Economic Studies, 77(2), 417-458.

Becker, S. O., Hornung, E., \& Woessmann, L. (2011). Education and catch-up in the industrial revolution. American Economic Journal: Macroeconomics, 3, 92-126.

Belenzon, S., \& Schankerman, M. (2013). Spreading the word: Geography, policy and knowledge spillovers. Review of Economics and Statistics, 95(3), 884-903.

Bercovitz, J., \& Feldman, M. (2008). Academic entrepreneurs: Organizational change at the individual level. Organization Science, 19, 69-89.

Bischoff, K., Volkmann, C. K., \& Audretsch, D. B. (2018). Stakeholder collaboration in entrepreneurship education: An analysis of the entrepreneurial ecosystems of European higher educational institutions. Journal of Technology Transfer, 43(1), 20-46.

Boh, W. F., De-Haan, U., \& Strom, R. (2016). University technology transfer through entrepreneurship: Faculty and students in spinoffs. Journal of Technology Transfer, 41(4), 661-669.

Boschma, R. (2005). Proximity and innovation: A critical assessment. Regional Studies, 39(1), 61-74.

Bozeman, B., \& Mangematin, V. (2004). Editor's introduction: Building and deploying scientific and technical human capital. Research Policy, 33, 565-568.

Brambor, T., Clark, W. R., \& Golder, M. (2006). Understanding interaction models: Improving empirical analyses. Political Analysis, 14(1), 63-82.

Bulte, C. V. D., \& Moenaert, R. K. (1998). The effects of R\&D team co-location on communication patterns among R\&D, marketing, and manufacturing. Management Science, 44(11), 1-18.

Cameron, C. A., \& Trivedi, P. (2009). Microeconometrics using STATA. College Station: STATA Press Publication.

Cantoni, D., \& Yuchtman, N. (2014). Medieval universities, legal institutions, and the commercial revolution. Quarterly Journal of Economics, 129, 823-887.

Carlsson, B., Acs, Z. J., Audretsch, D. B., \& Braunerhjelm, P. (2009). Knowledge creation, entrepreneurship, and economic growth: A historical review. Industrial and Corporate Change, 18, 1193-1229.

Catalini C. (2015). Microgeography and the direction of inventive activity. In Rotman School of Management Working Paper No. 2126890.

Clarysse, B., Tartari, V., \& Salter, A. (2011). The impact of entrepreneurial capacity, experience and organizational support on academic entrepreneurship. Research Policy, 40, 1084-1093.

Connelly, J. (2000). Captive University: The sovietization of East German, Czech, and Polish higher education, 1945-1956. North Carolina: University of North Carolina Press.

Cumming, D. J., \& Fischer, E. (2012). Publicly funded business advisory services and entrepreneurial outcomes. Research Policy, 41, 467-481.

D'Este, P., \& Patel, P. (2007). University-industry linkages in the UK: What are the factors underlying the variety of interactions with industry. Research Policy, 36, 1295-1313.

Di Gregorio, D., \& Shane, S. (2003). Why do some universities generate more start-ups than others? Research Policy, 32, 209-227.

Drucker, P. F. (1998). From capitalism to knowledge society. In N. Dale (Ed.), The knowledge economy (pp. 15-34). Boston: Butterworth-Heinemann.

Etzkowitz, H. (2000). The second academic revolution: MIT and the rise of entrepreneurial science. London: Gordon and Breach.

Etzkowitz, H. (2003). Research groups as 'quasi-firms': The invention of the entrepreneurial university. Research Policy, 32, 109-121.

EXIST. 2013. Retrieved December 5, 2013 from http://www.exist.de/.

Festinger, L., Schachter, S., \& Back, K. (1963). Social pressures in informal groups: A study of human factors in housing. Stanford: Stanford University Press.

Fini, R., Grimaldi, R., Santoni, S., \& Sobrero, M. (2011). Complements or substitutes? The role of universities and local context in supporting the creation of academic spin-offs. Research Policy, 40, 1113-1127.

Fritsch, M., \& Aamoucke, R. (2013). Regional public research, higher education, and innovative start-ups: An empirical investigation. Small Business Economics, 41, 865-885.

Fritsch, M., \& Falck, O. (2007). New business formation by industry over space and time: A multi-dimensional analysis. Regional Studies, 41, 157-172.

Glaeser, E., \& Sacerdote, B. (2000). The social consequences of housing. Journal of Housing Economics, $I X, 1-23$.

Goethner, M., Obschonka, M., Silbereisen, R. K., \& Cantner, U. (2012). Scientists' transition to academic entrepreneurship: Economic and psychological determinants. Journal of Economic Psychology, 33, 628-641. 
Grandi, A., \& Grimaldi, R. (2005). Academic's organizational characteristics and the generation of successful business ideas. Journal of Business Venturing, 20, 821-845.

Grinblatt, M., Keloharju, M., \& Ikäheimo, S. (2008). Social influence and consumption: Evidence from the automobile purchases of neighbors. Review of Economics and Statistics, 90(4), 735-753.

Gulbrandsen, M., \& Smeby, J. C. (2005). Industry funding and university professors' research performance. Research Policy, 34, 932-950.

Heblich, S., \& Slavtchev, V. (2014). Parent Universities and the Location of Academic Startups. Small Business Economics, 42(2014), 1-15.

Helsley, R. W., \& Strange, W. C. (1991). Agglomeration economies and urban capital markets. Journal of Urban Economics, 29, 96-112.

Holahan, C. J., Wilcox, B. L., \& Burnam, M. A. (1978). Social satisfaction and friendship formation as a function of floor level in high-rise student housing. Journal of Applied Psychology, LXIII, 527-529.

Howells, J. R. L. (2002). Tacit knowledge, innovation and economic geography. Urban Studies, 39, 871-884.

Hsu, D. H., Roberts, E. B., \& Eesley, C. E. (2007). Entrepreneurs from technology-based universities: Evidence from MIT. Research Policy, 36, 768-788.

Jacobs, J. (1969). The economy of cities. New York: Random House.

Jaffe, A. B., Trajtenberg, M., \& Henderson, R. (1993). Geographic localization and knowledge spillovers as evidenced by patent citations. Quarterly Journal of Economics, 108, 577-598.

Kenney, M., \& Goe, R. W. (2004). The role of social embeddedness in professorial entrepreneurship: A comparison of electrical engineering and computer science at UC Berkeley and Stanford. Research Policy, 33, 691-707.

Kirby, D. A. (2004). Entrepreneurship education: Can business schools meet the challenge? Education + Training, 46(8/9), 510-519.

Kulicke, M. (2014). 15 years of EXIST “University-based start-up programmes”-Development of the EXUST funding programme between 1998 and 2013. Karlsruhe: Fraunhofer ISI.

Kuratko, D. F. (2005). The emergence of entrepreneurship education: Development, trends, and challenges. Entrepreneurship Theory and Practice, 29(5), 577-598.

Landry, R., Amara, N., \& Rherrad, I. (2006). Why are some university researchers more likely to create spin-offs than others? Evidence from Canadian universities. Research Policy, 35, 1599-1615.

Link, A. N., \& Scott, J. T. (2005). Opening the ivory tower's door: An analysis of the determinants of the formation of U.S. University spin-off companies. Research Policy, 34, 1106-1112.

Link, A. N., \& Scott, J. T. (2010). Government as entrepreneur: Evaluating the commercialization success of SBIR projects. Research Policy, 39, 589-601.

Link, A. N., Siegel, D. S., \& Bozeman, B. (2007). An empirical analysis of the propensity of academics to engage in informal university technology transfer. Industrial and Corporate Change, 16, 641-655.

Lockett, A., Siegel, D. S., Wright, M., \& Ensley, M. D. (2005). The creation of spinoffs firms at public research institutions: Managerial and policy implications. Research Policy, 34, 981-993.

Lockett, A., \& Wright, M. (2005). Resources, capabilities, risk capital and the creation of university spin-out companies. Research Policy, 34, 1043-1057.

Marmaros, D., \& Sacerdote, B. (2006). How do friendships form? Quarterly Journal of Economics, 121(1), 79-119.

Martin, B. C., McNally, J. J., \& Kay, M. J. (2013). Examining the formation of human capital in entrepreneurship: A meta-analysis of entrepreneurship education outcomes. Journal of Business Venturing, 28(2), 211-224.

Mayer, A., \& Puller, S. L. (2008). The old boy (and girl) network: Social network formation on university campuses. Journal of Public Economics, 92(1-2), 329-347.

Murray, F. (2004). The role of academic inventors in entrepreneurial firms: Sharing the laboratory life. Research Policy, 33, 643-659.

Muscio, A. (2013). University-industry linkages: What are the determinants of distance in collaborations? Papers in Regional Science, 92, 715-739.

Nanda, R., \& Sørensen, R. J. B. (2010). Workplace peers and entrepreneurship. Management Science, 56, 1116-1126.

Noseleit, F., Slavtchev, V. (2010). 'Universities' Foundation and Regional Development'. In ERSA Conference Paper.

O’Shea, R. P., Allen, T. J., Chevalier, A., \& Roche, F. (2005). Entrepreneurial orientation, technology transfer and spinoff performance of U.S. Universities. Research Policy, 34, 994-1009.

O'Shea, R. P., Chugh, H., \& Allen, T. J. (2008). Determinants and consequences of university spinoff activity: A conceptual framework. Journal of Technology Transfer, 33, 653-666.

OECD. (2003). Turning science into business, patenting, and licensing at public research organizations. Paris: OECD. 
Ott, T. (2001). From concentration to deconcentration: Migration patterns in the post-socialist city. Cities, $18,403-412$.

Perkmann, et al. (2013). Academic engagement and commercialisation: A review of the literature on university-industry relations. Research Policy, 42, 423-442.

Powers, J. B., \& McDougall, P. P. (2005). University start-up formation and technology licensing with firms that go public: A resource-based view of academic entrepreneurship. Journal of Business Venturing, 20, 291-311.

Rasmussen, E. (2011). Understanding academic entrepreneurship: Exploring the emergence of university spin-off ventures using process theories. International Small Business Journal, 29, 448-471.

Rasmussen, E., \& Borch, O. J. (2010). University capabilities in facilitating entrepreneurship: A longitudinal study of spin-off ventures at mid-range universities. Research Policy, 39, 602-612.

Rasmussen, E., Mosey, S., \& Wright, M. (2014). The influence of university departments on the evolution of entrepreneurial competencies in spin-off ventures. Research Policy, 43, 92-106.

Rivera, M. T., Sonderstrom, S. B., \& Uzzi, B. (2010). Dynamics of dyads in social networks: Assortative, relational, and proximity mechanisms. Annual Review of Sociology, 36(1), 91-115.

Rothaermel, F. T., Agung, S. D., \& Jiang, L. (2007). University entrepreneurship: A taxonomy of the literature. Industrial and Corporate Change, 16, 691-791.

Sacerdote, B. (2001). Peer effects with random assignment: Results for Dartmouth roommates. Quarterly Journal of Economics, 116(2), 681-704.

Saxenian, A. (1994). Regional advantage: Culture and competition in silicon valley and route 128. Harvard: Harvard University Press.

Shane, S. A. (2000). Prior knowledge and the discovery of entrepreneurial opportunities. Organization Science, 11, 448-469.

Shane, S. A. (2004). Academic entrepreneurship: University spinoffs and wealth creation. Cheltenham: Edward Elgar.

Siegel, D. M., Wright, M., \& Lockett, A. (2007). The rise of entrepreneurial activity at universities: Organizational and societal implications. Industrial and Corporate Change, 16, 489-504.

Singh, J., \& Marx, M. (2013). Geographic constraints on knowledge spillovers: Political borders vs. spatial proximity. Management Science, 59(9), 2056-2078.

Sorenson, O., \& Stuart, T. E. (2001). Syndication networks and the spatial distribution of venture capital financing. American Journal of Sociology, 106, 1546-1588.

Stock, J. H., Wright, J. H., \& Yogo, M. (2002). A survey of weak instruments and weak identification in generalized method of moments. Journal of Business \& Economic Statistics, 20, 518-529.

Storper, M., \& Venables, A. J. (2004). Buzz: Face-to-face contact and the urban economy. Journal of Economic Geography, 4, 351-370.

Tartari, V., Perkmann, M., \& Salter, A. (2014). In good company: The influence of peers on industry engagement by academic scientists. Research Policy, 43(7), 1189-1203.

Thursby, J. G., \& Thursby, M. C. (2002). Who is selling the ivory tower? Sources of growth in university licensing. Management Science, 48(1), 90-104.

Van Looy, B., Landoni, P., Callaert, J., van Pottelsberghe, B., Sapsalis, E., \& Debackere, K. (2011). Entrepreneurial effectiveness of European universities: An empirical assessment of antecedents and trade-offs. Research Policy, 40, 553-564.

Vohora, A., Wright, M., \& Lockett, A. (2004). Critical junctures in the development of university hightech spinout companies. Research Policy, 33, 147-175.

Wennberg, K., Wiklund, J., \& Wright, M. (2011). The effectiveness of university knowledge spillovers: Performance differences between university spinoffs and corporate spinoffs. Research Policy, 40, $1128-1143$.

Wright, M. (2014). Academic entrepreneurship, technology transfer and society: Where next? Journal of Technology Transfer, 39, 322-334.

Wright, M., Piva, E., Mosey, S., \& Lockett, A. (2009). Academic entrepreneurship and business schools. Journal of Technology Transfer, 34, 560-587.

Zimmerman, D. J. (2003). Peer effects in academic outcomes: Evidence from a natural experiment. Review of Economics and Statistics, 85(1), 9-23.

Publisher's Note Springer Nature remains neutral with regard to jurisdictional claims in published maps and institutional affiliations. 